\title{
Serial:Powerpoint Presentasi: HIDROLOGI/ KONDISI AIR DAERAH KARST
}

Oleh :

Tjahyo Nugroho Adji (Kelompok Studi Karst Fakultas Geografi UGM) 


\section{AIR DI DAERAH KARST}

Ilmu yang mempelajari air di bumi adalah HIDROLOGI

- HIDRO = air (bhs. latin)

- LOGI = ilmu 


\section{SIKLUS/LINGKARAN HIDROLOGI}

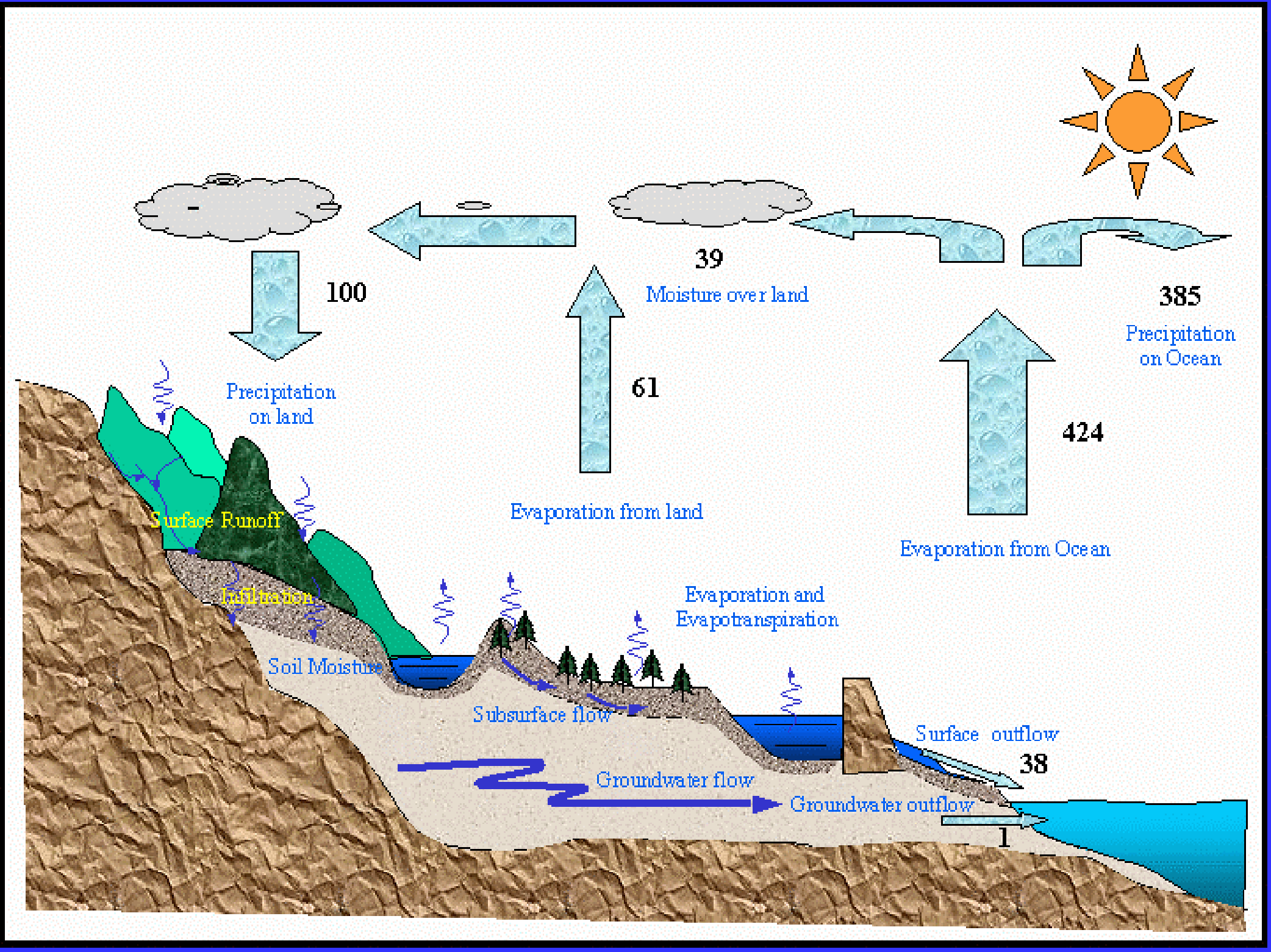




\section{AIRTANAH}

$\checkmark$ air yang mengisi rongga-rongga batuan di bawah permukaan tanah pada zone jenuh air.

$\checkmark$ sumber utama : hujan

$\checkmark$ airtanah bergerak paling cepat $10 \mathrm{~m} /$ hari paling lambat $1 \mathrm{~m} /$ tahun 


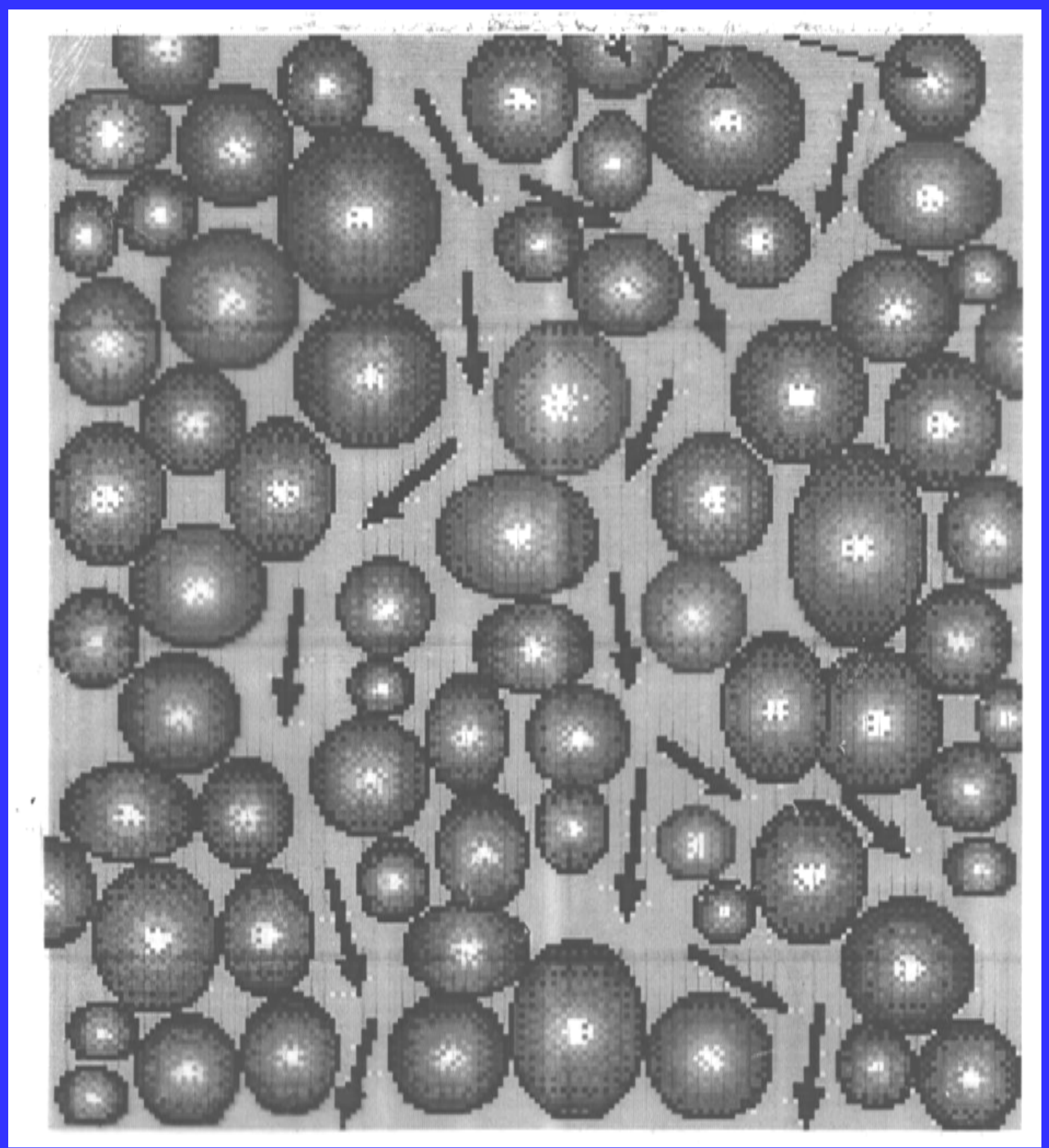




\section{Mengapa Airtanah Penting ??}

Groundwater and the world's freshwater supply

World water supply

(tresh and saline)

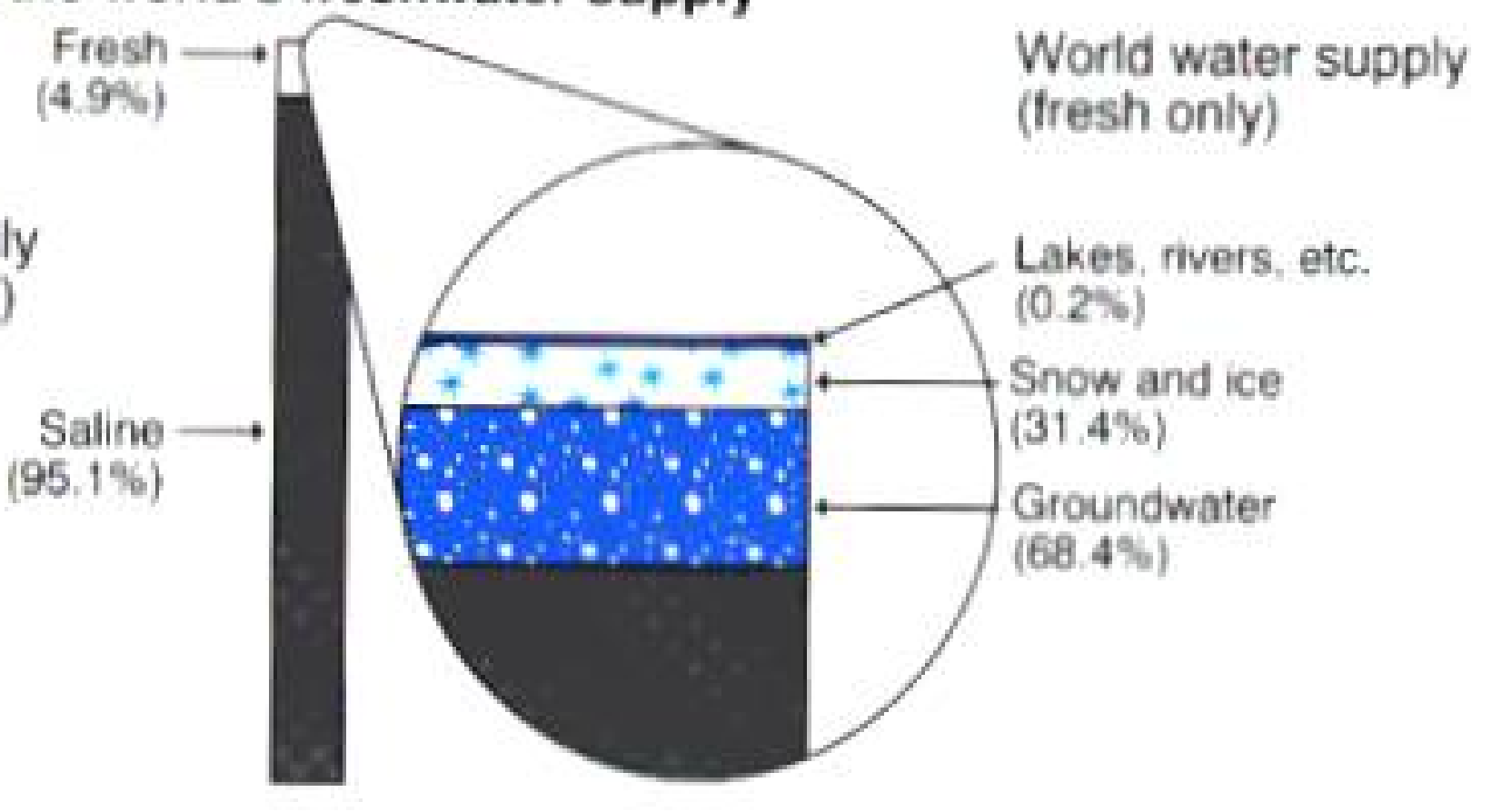

\section{0 juta orang tergantung pada airtanah}




\section{KONDISI AIRTANAH DI KARST}

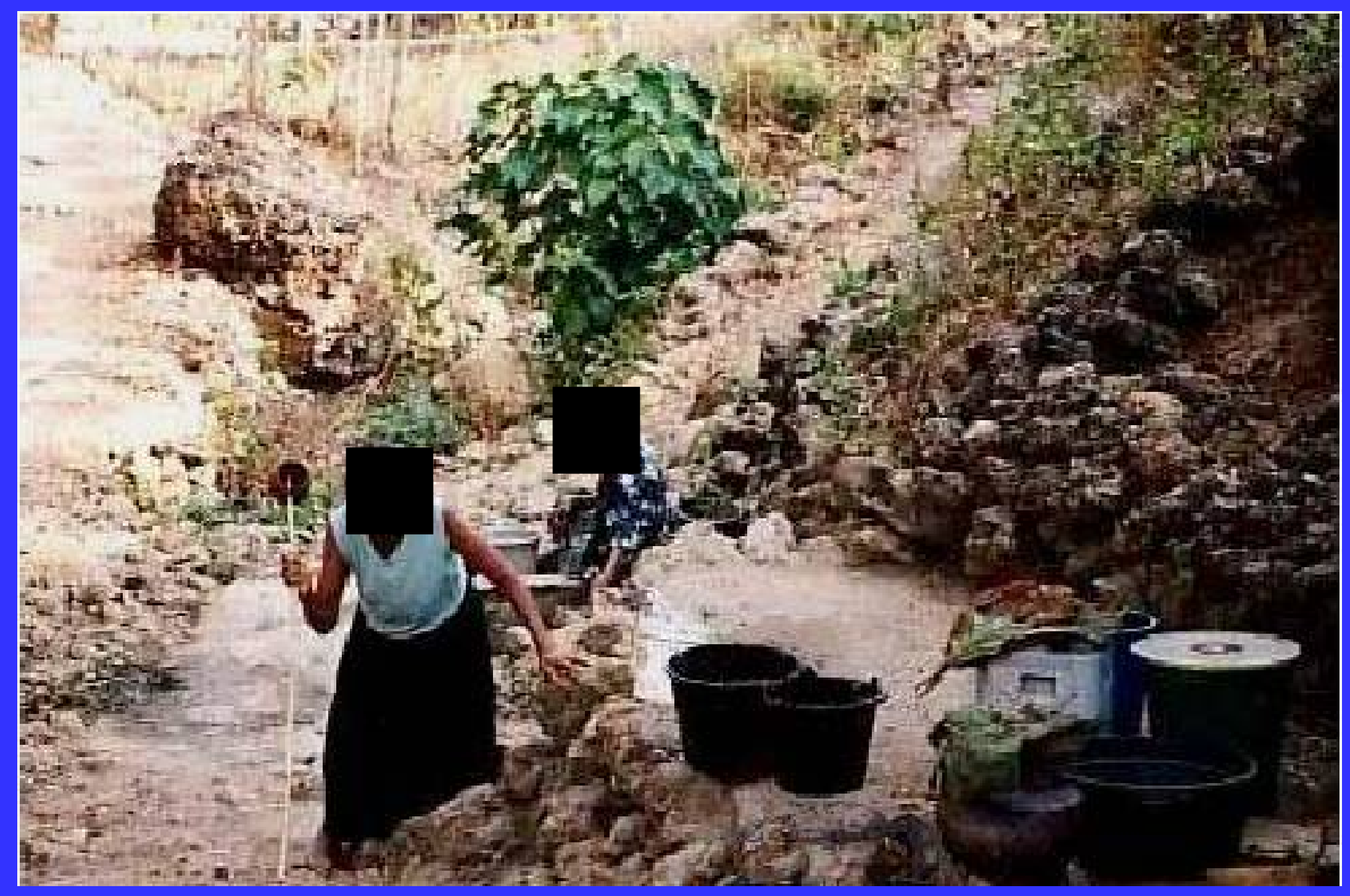




\section{Apakah betul air di karst hanya sedikit?}

Potensi air di suatu wilayah secara garis besar dipengaruhi oleh 3 faktor utama :

1. Iklim

2. Jenis batuan

3. Topografi/lereng 
Bagaimana hujan yang jatuh di Tepus ( kekeringan) dibandingkan yang jatuh di sekitar Kota Yogyakarta?

\section{Stasiun Hujan Yogyakarta = \\ 3000 - $3500 \mathrm{~mm} / \mathrm{tahun}$}

Stasiun Hujan Panggang dan Tepus = 2800 - $3700 \mathrm{~mm} / \mathrm{tahun}$

\section{SAMA BAIKNYA}




\section{Faktor Sifat Batuan - apa??}

- Batuan gamping adalah batuan yang sangat mudah larut oleh air

- Akibatnya berkembang apa yang dikenal sebagai LORONG-LORONG DI BAWAH TANAH 


\section{Kondisi batuan di Non Karst}

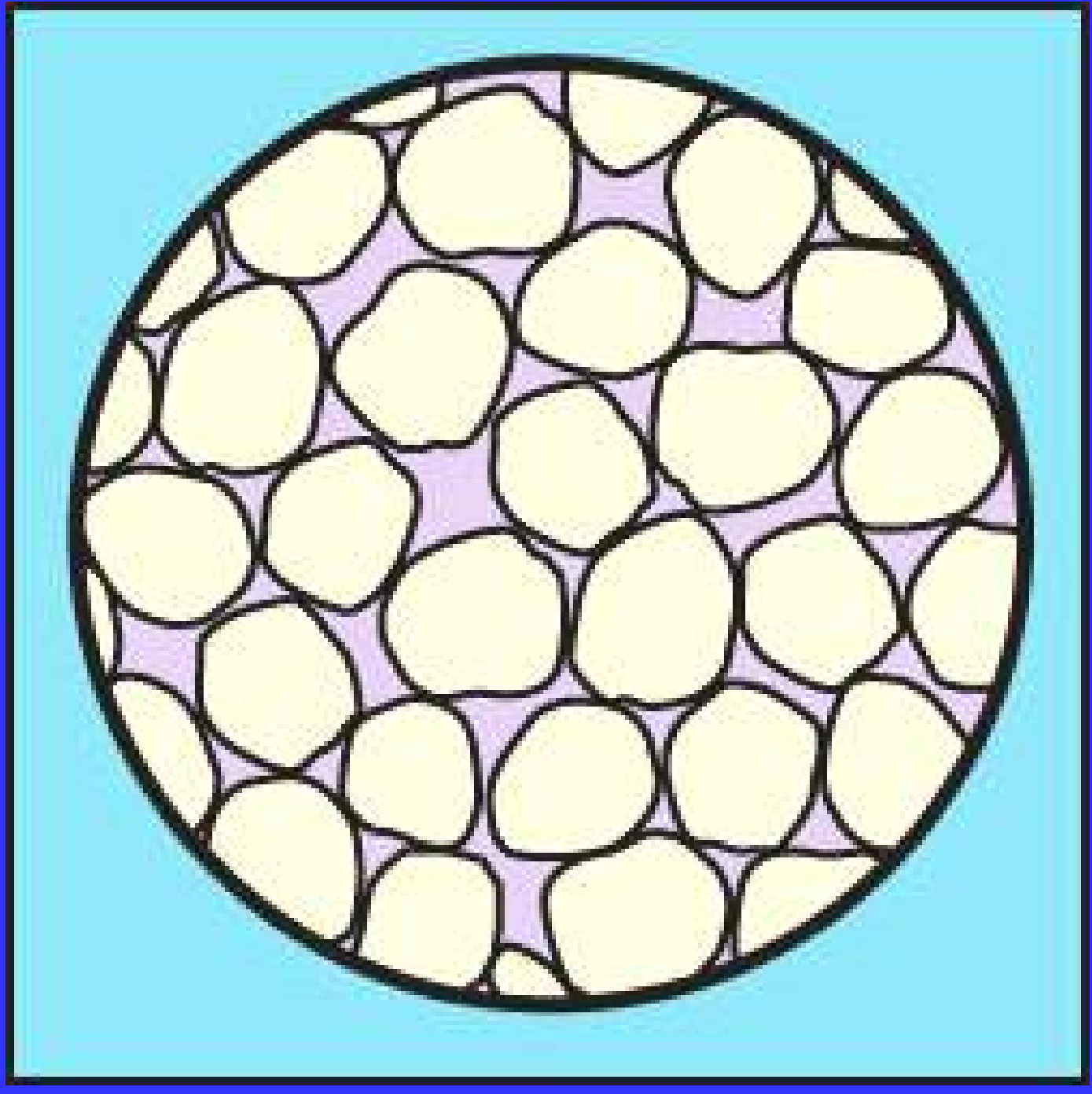




\section{Kondisi batuan di Karst}
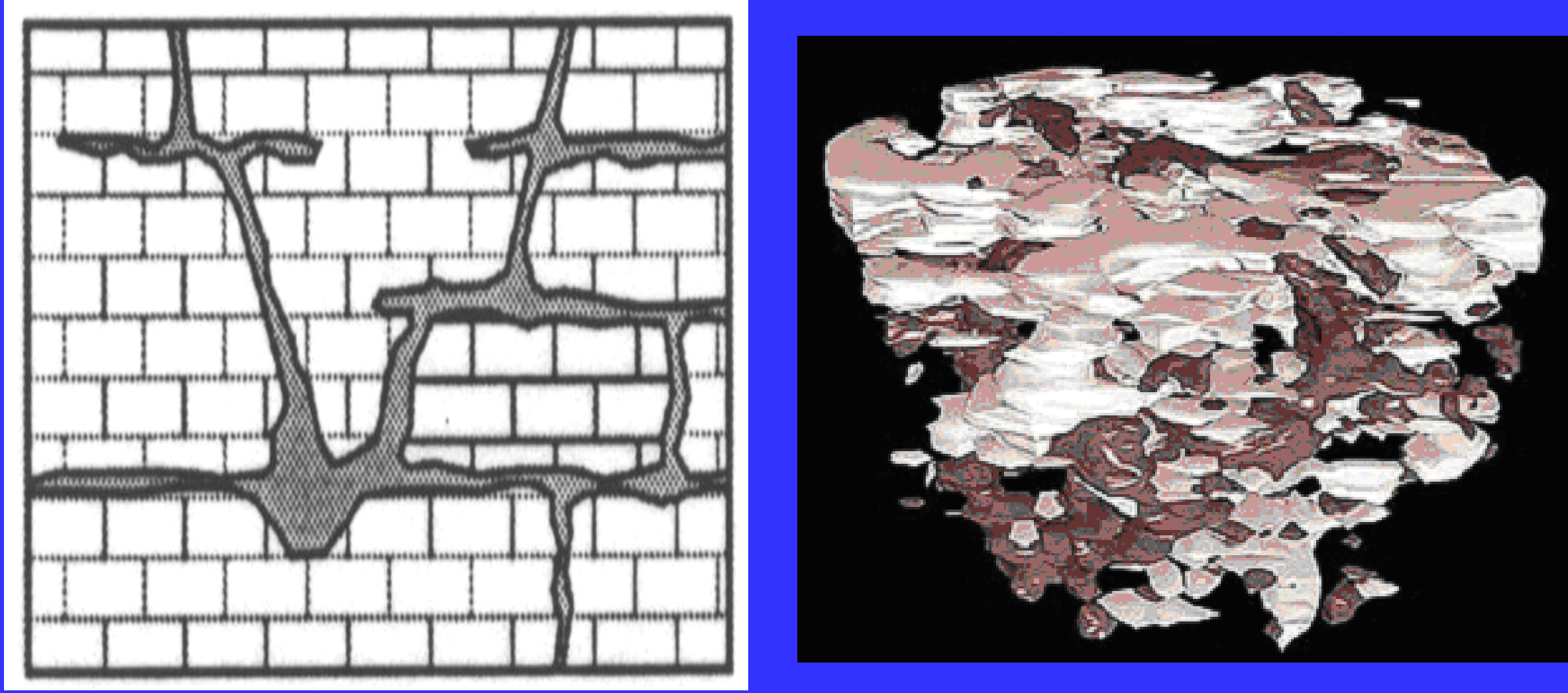


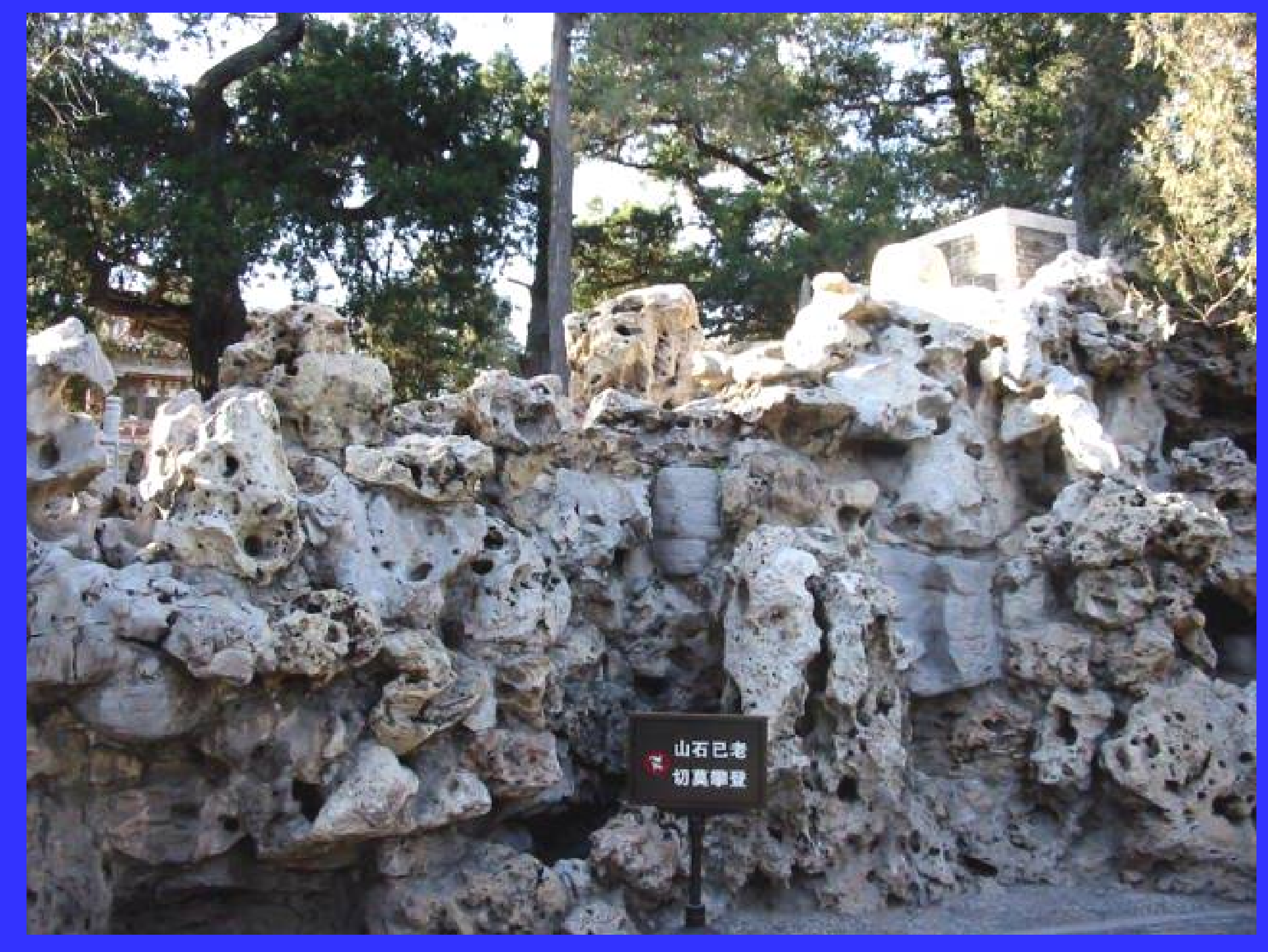




\section{Sehinggga :}

- Sungai hilang ke dalam tanah

- Tidak ada sungai di atas tanah

- Banyak lubang-lubang tempat air hilang

- Banyak gua

- Air dfjumpai sangat dalam (puluhan meter) pada sungai bawah tanah

- Banyak mataair

- Banyak sungai bawah tanah 


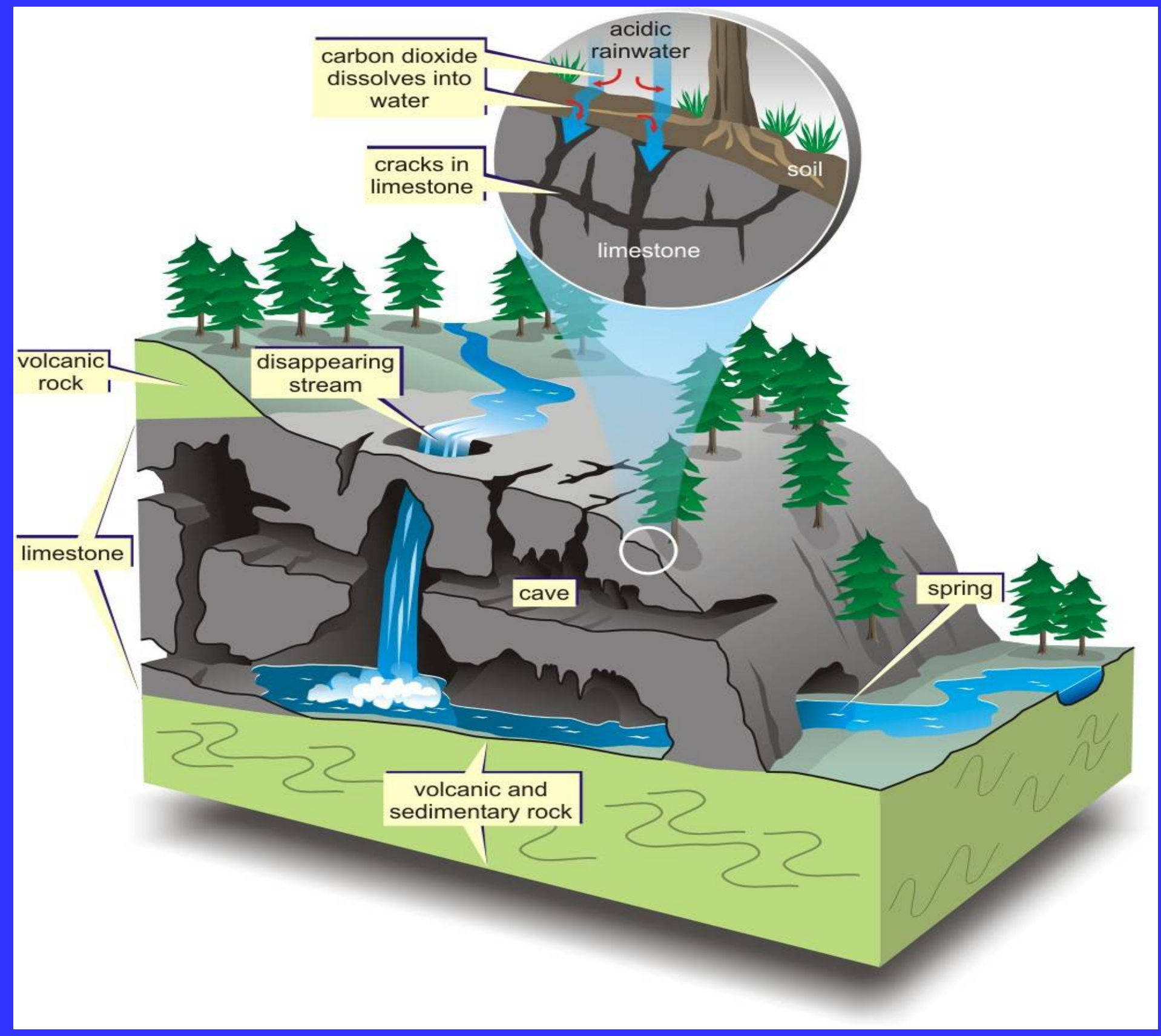




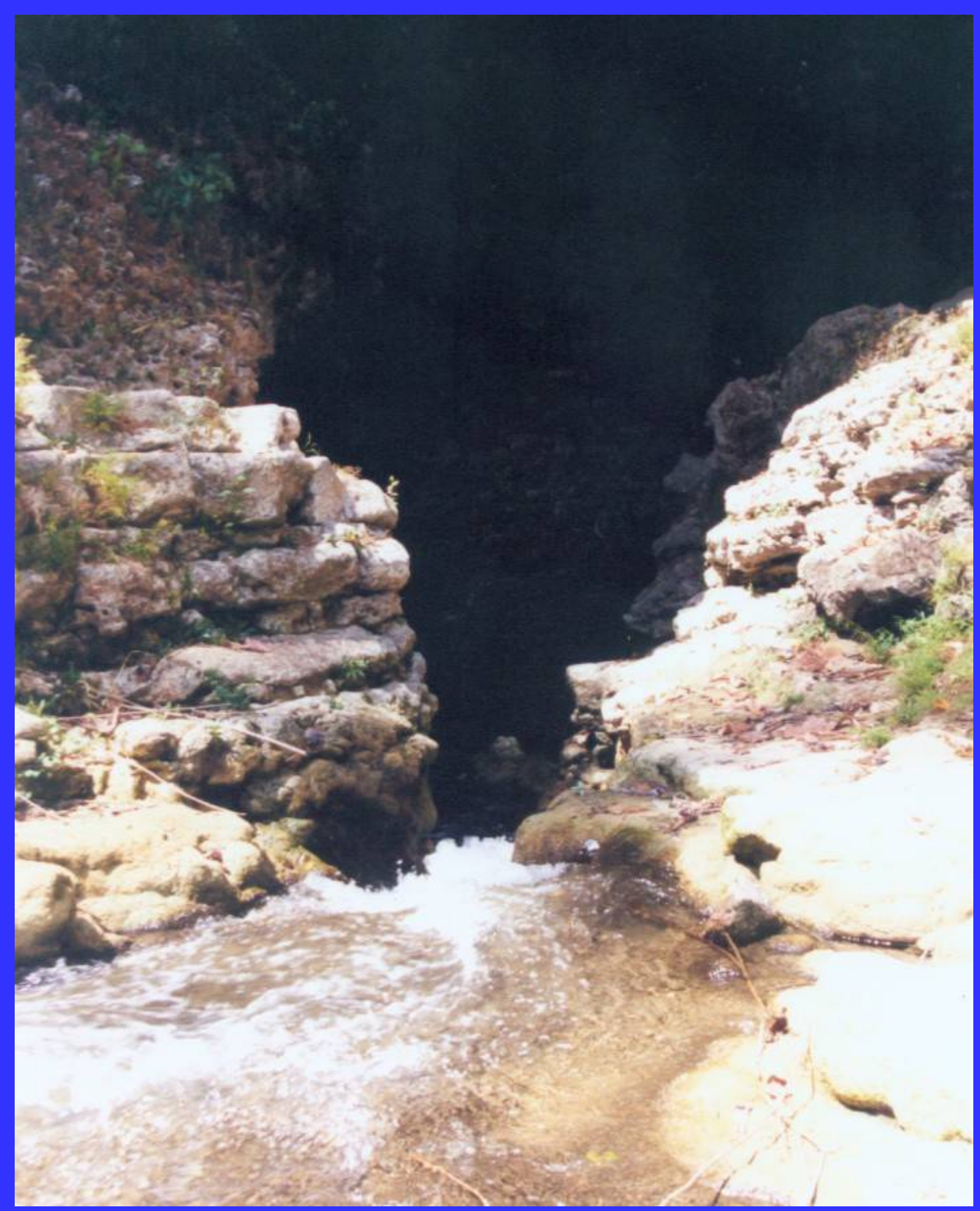



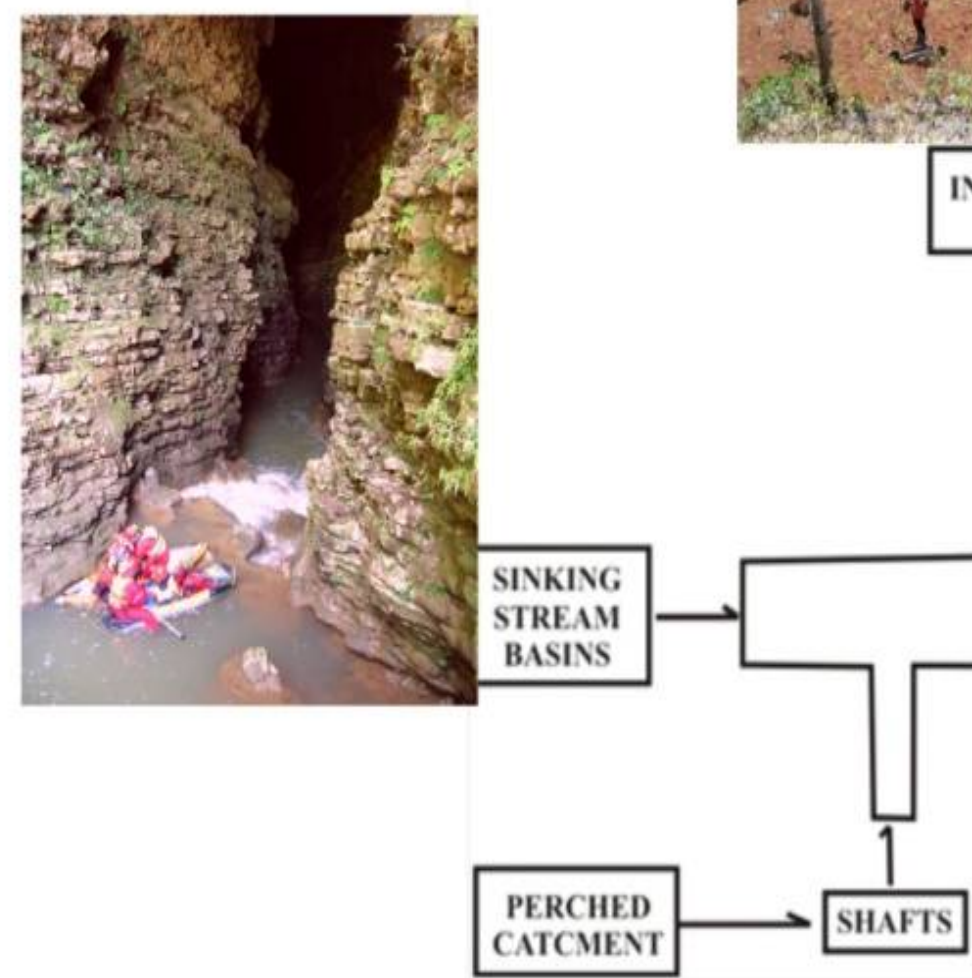

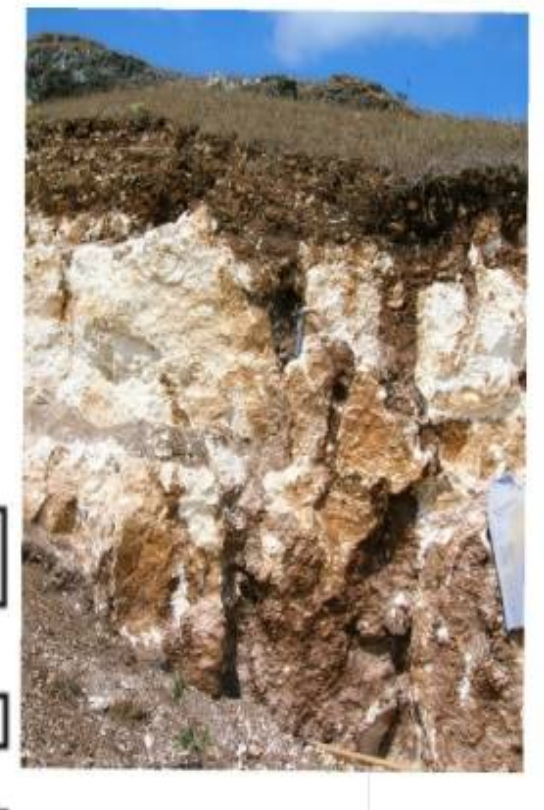

RUNOFF
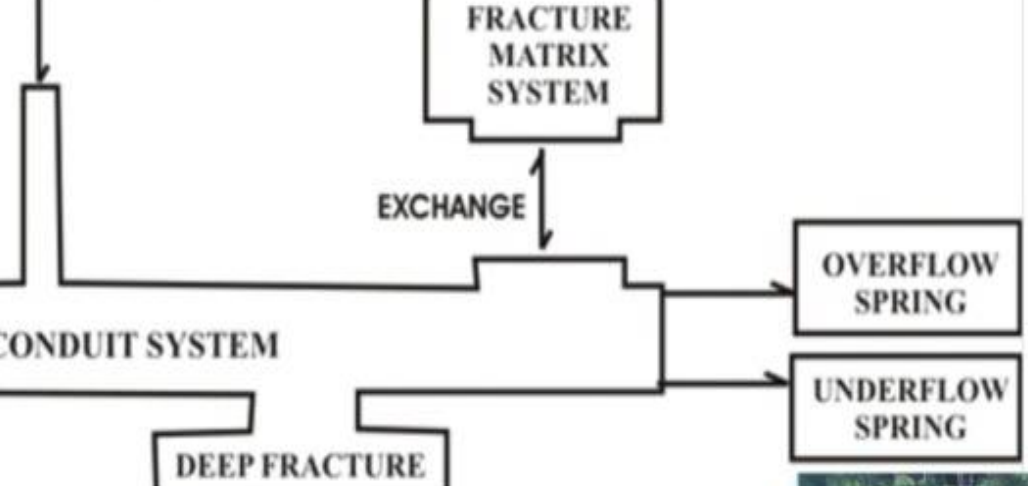

DEEPFRACTURE

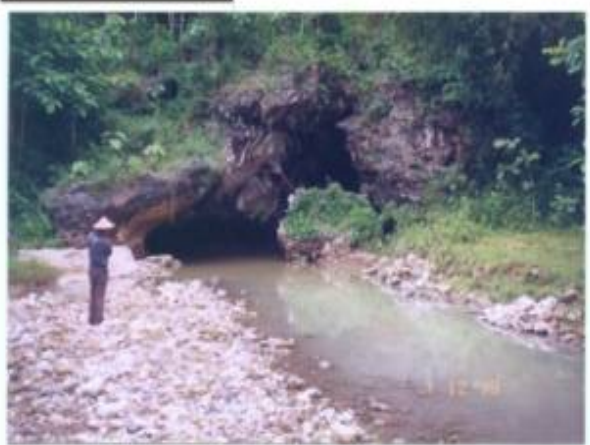

Sumber: White, 2007 


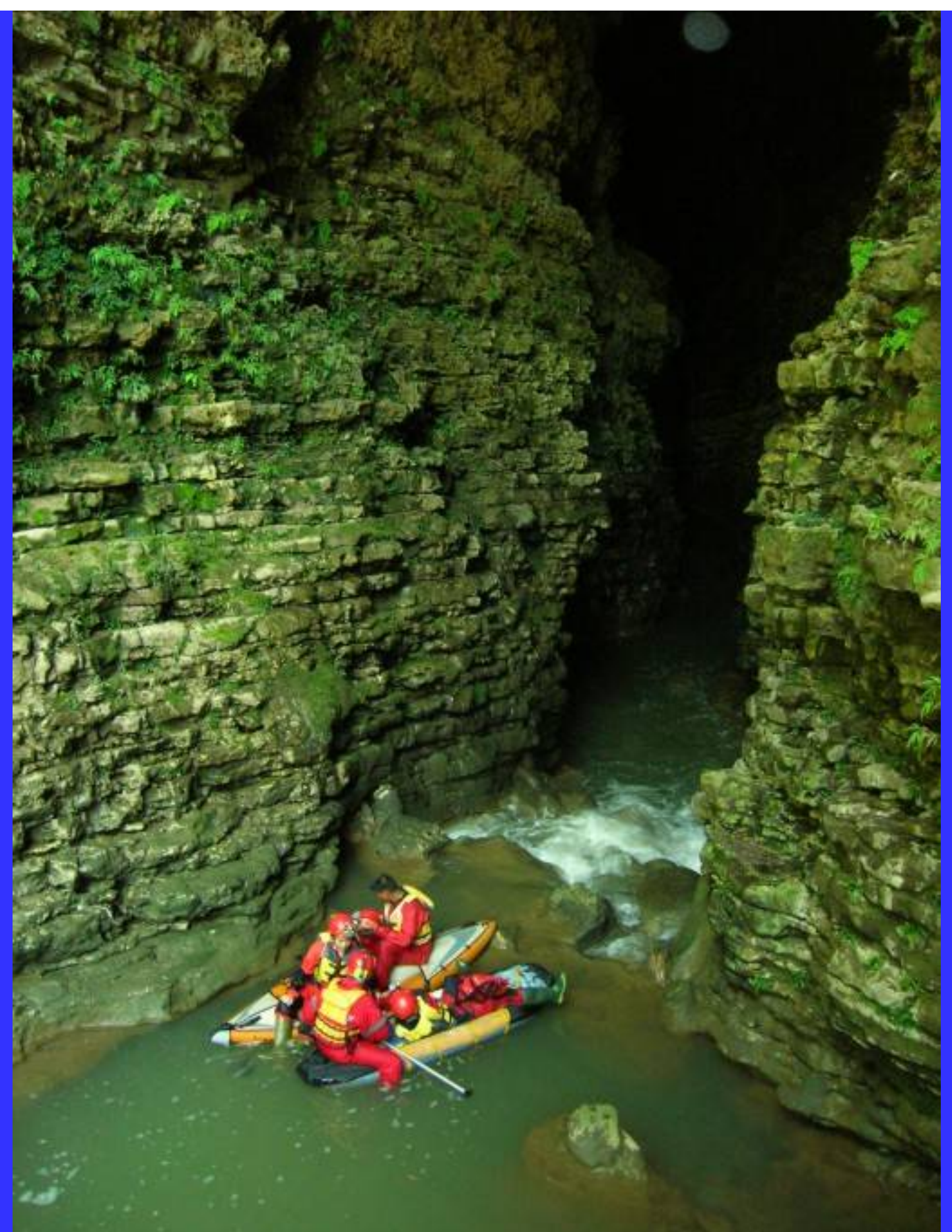




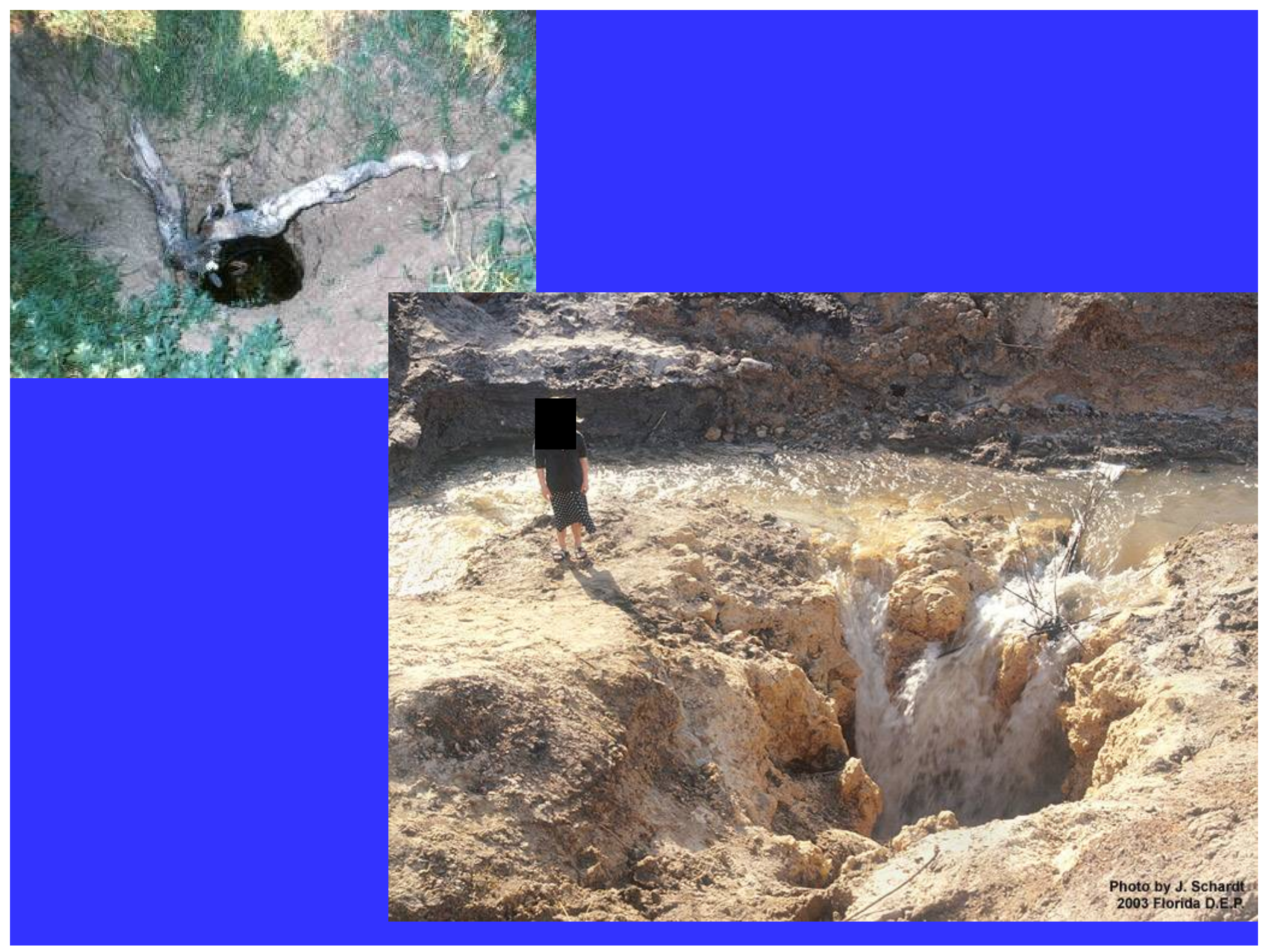




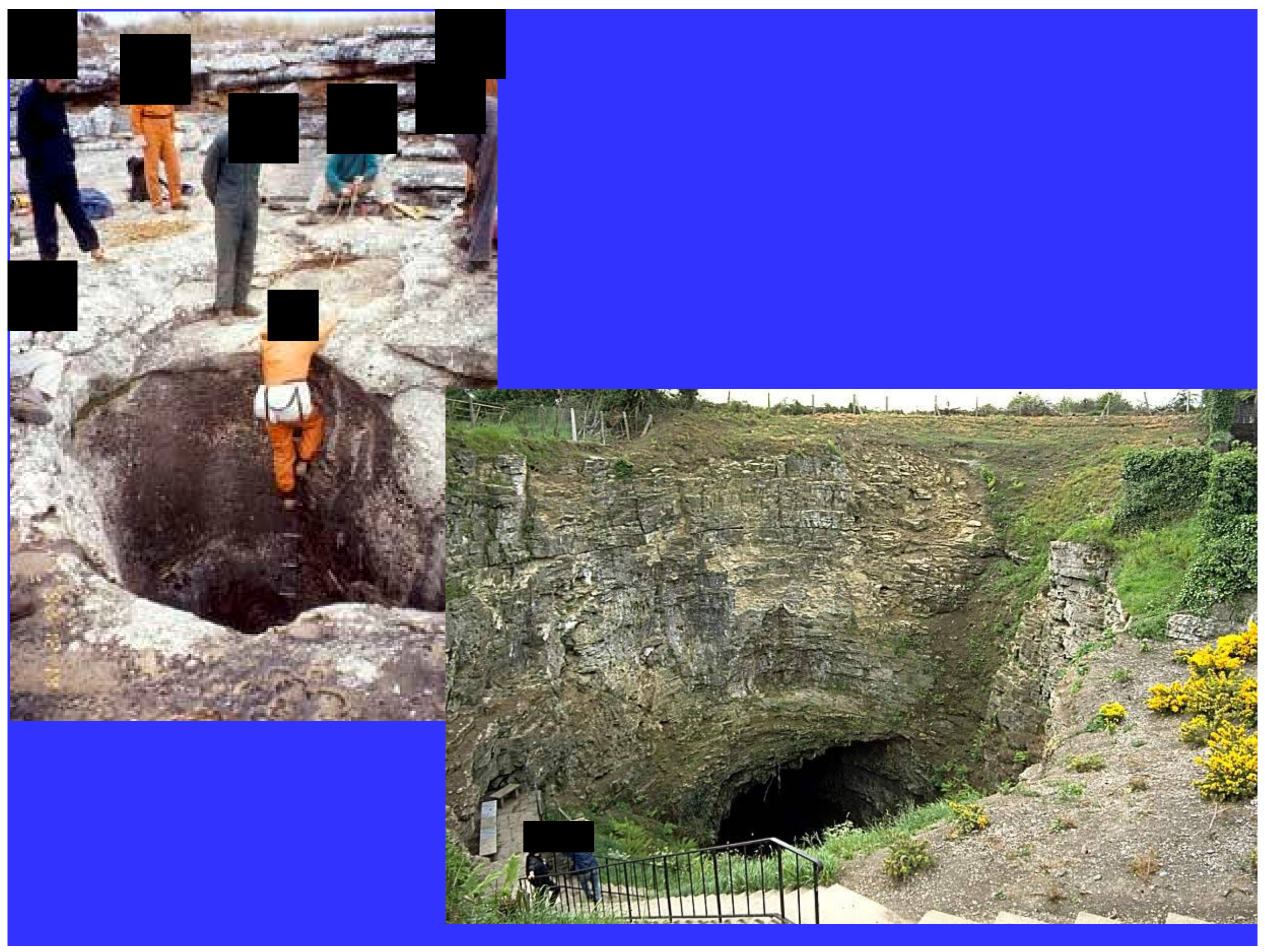




\section{TELAGA KARST (DOLINE)}

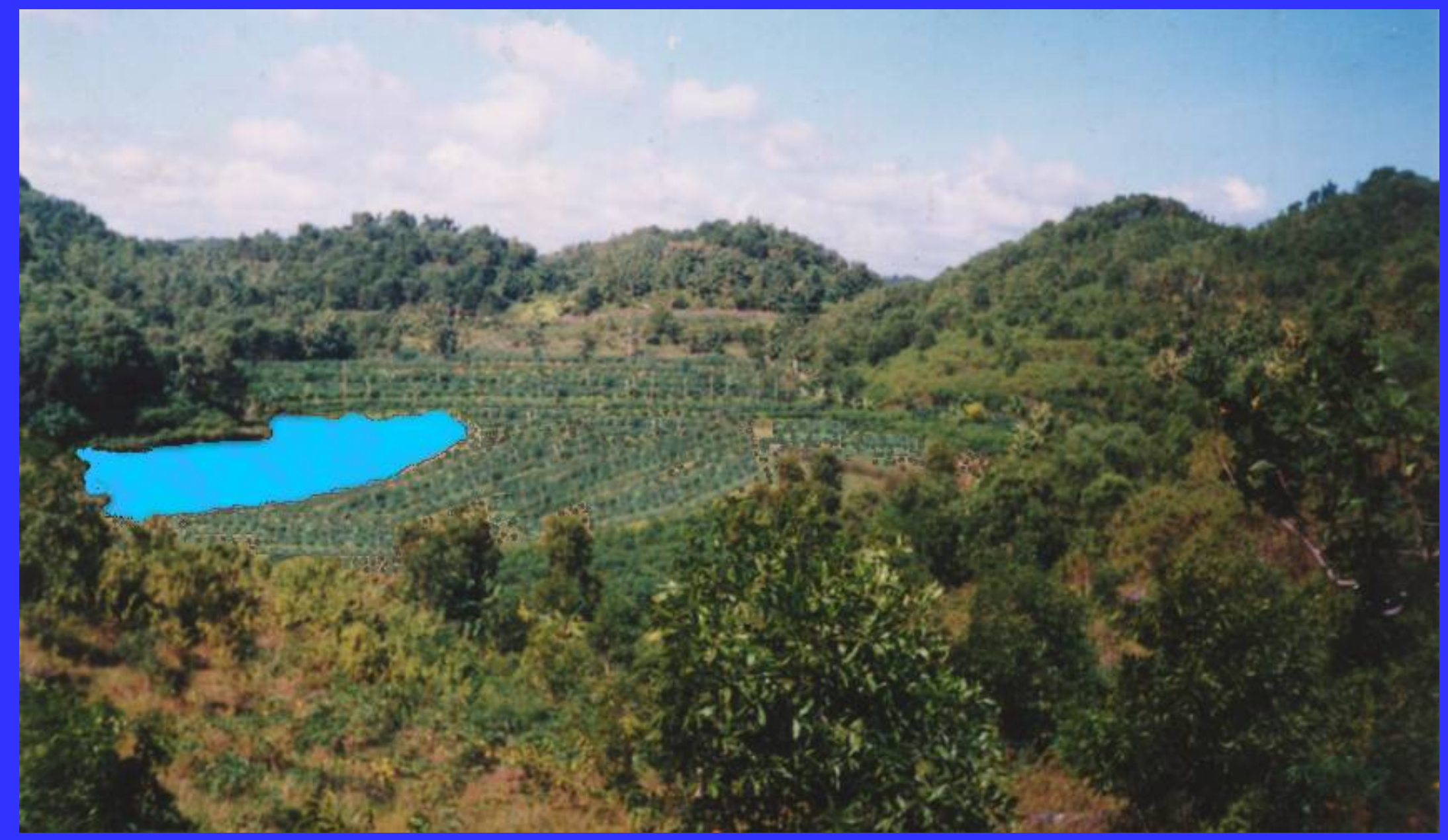



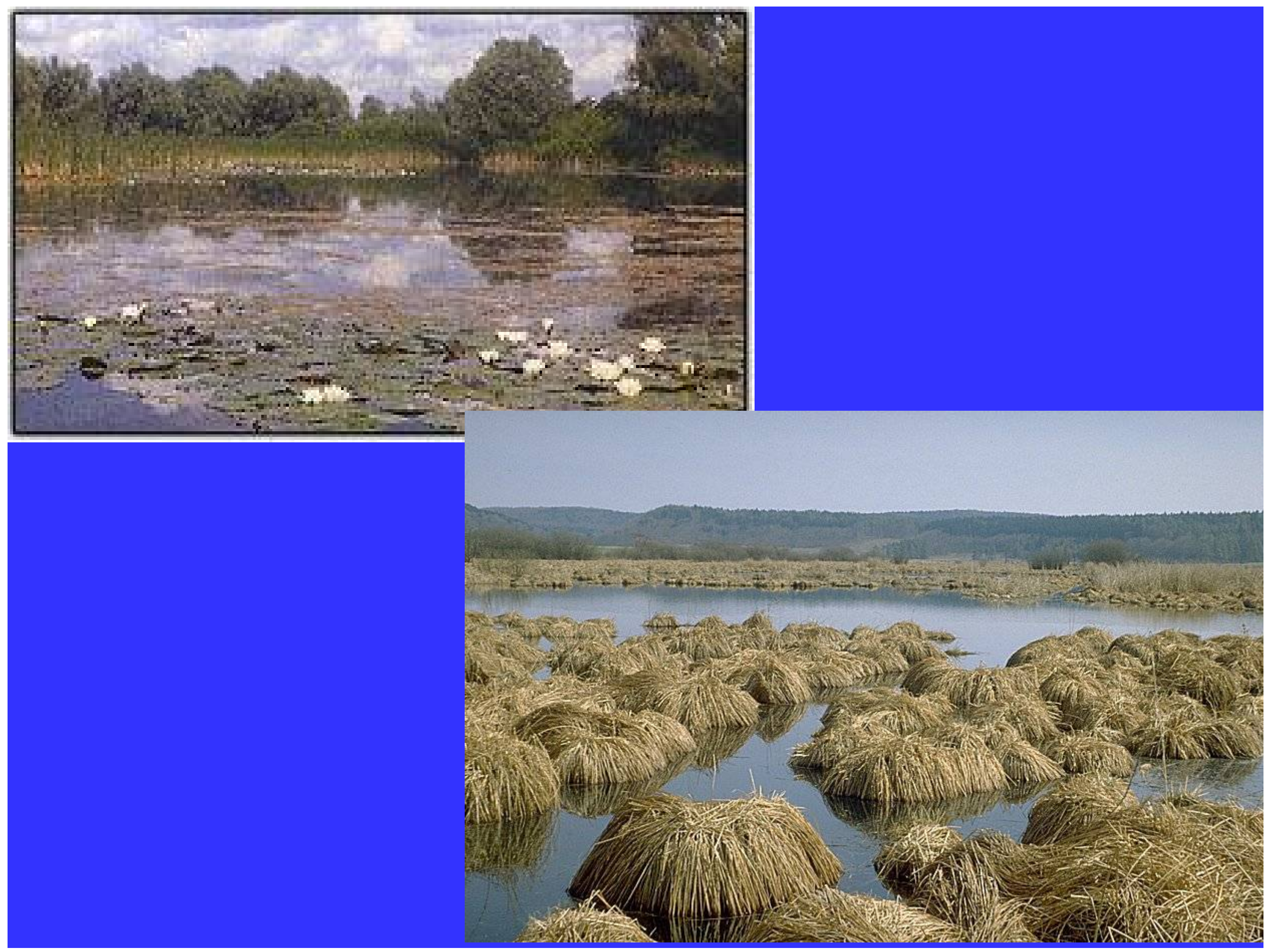


\section{Mengapa batuan karst bisa menyimpan air??}

- Karena ada proses pelarutan yang membuat rongga-rongga yang lama kelamaan bertambah besar

- Batuan sebelah atas akan terlapukkan dan membentuk tanah

- Tanah inilah yang kemudian mengisi ronggarongga tersebut dan menyimpan air

- Kemudian secara perlahan-lahan dialirkan ke sungai bawah tanah atau mataair 


\section{ZONATION OF A KARST AQUIFER}

RECHARGE AREA

1) Concentrated infiltration

2) Diffuse infiltration

3) Indirect infiltration
EPIPHREATIC ZONE

4) Transfer zone

5) Flow zone

6) Fossil conduits

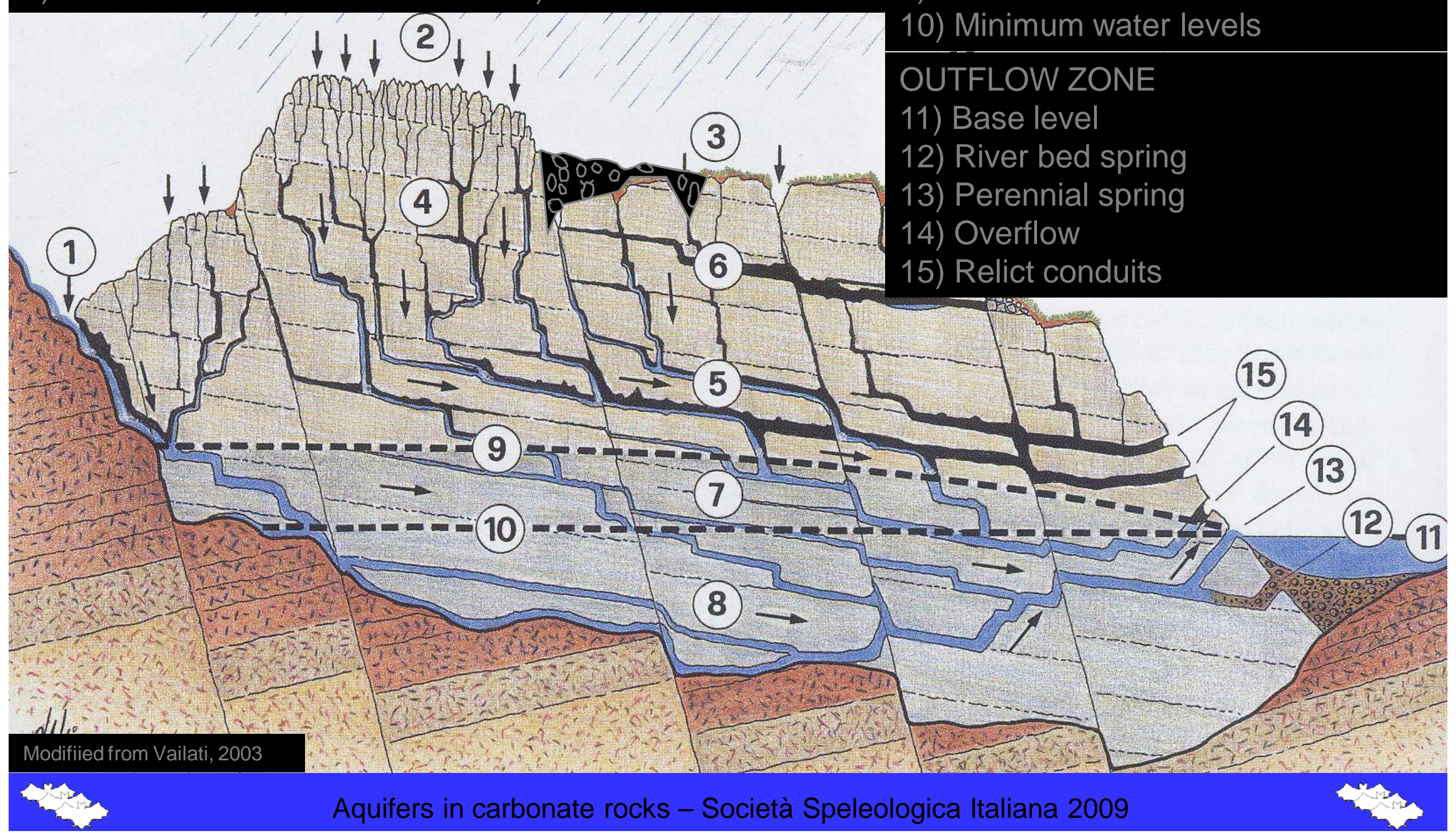

PHREATIC ZONE

7) Oscillation zone

8) Main conduits

9) Maximum water levels

10) Minimum water levels

OUTFLOW ZONE

15) Relict conduits 


\section{Dimanakah airtanah karst sebagian besar tersimpan ??}

- Di zona dekat permukaan bukit karst

- Kemudian dialirkan perlahan-lahan menuju sungai bawah tanah dan mataair 


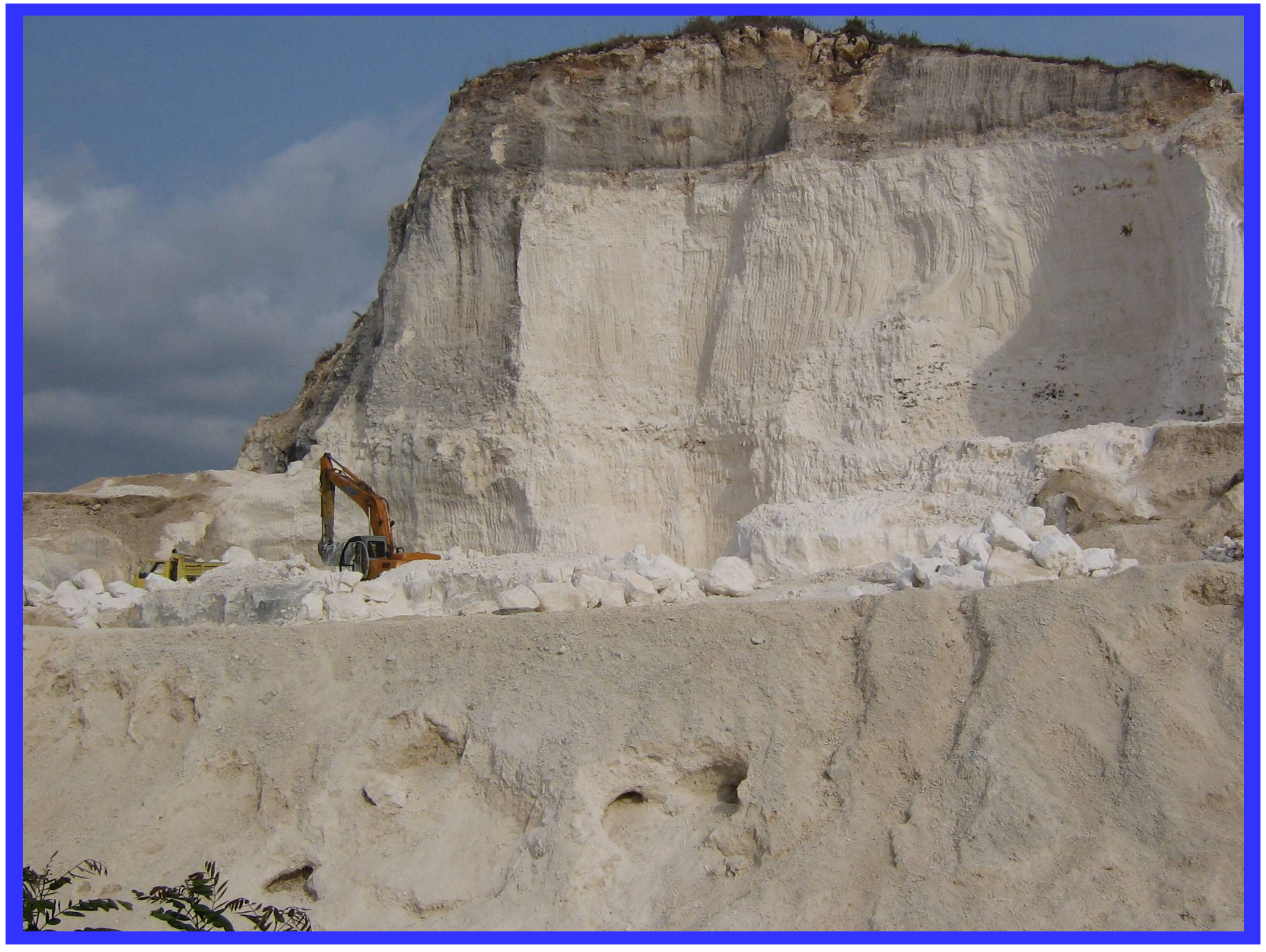




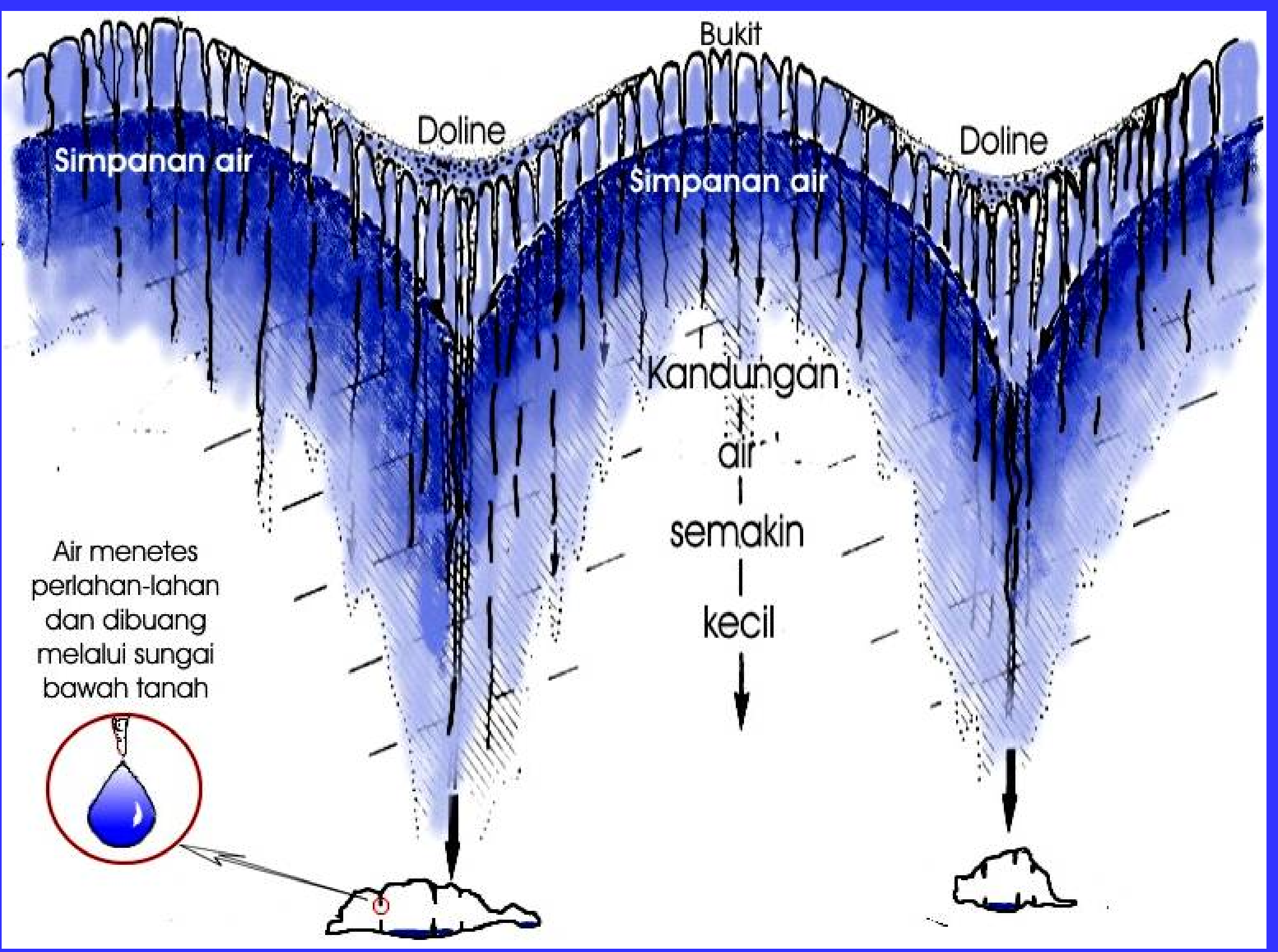




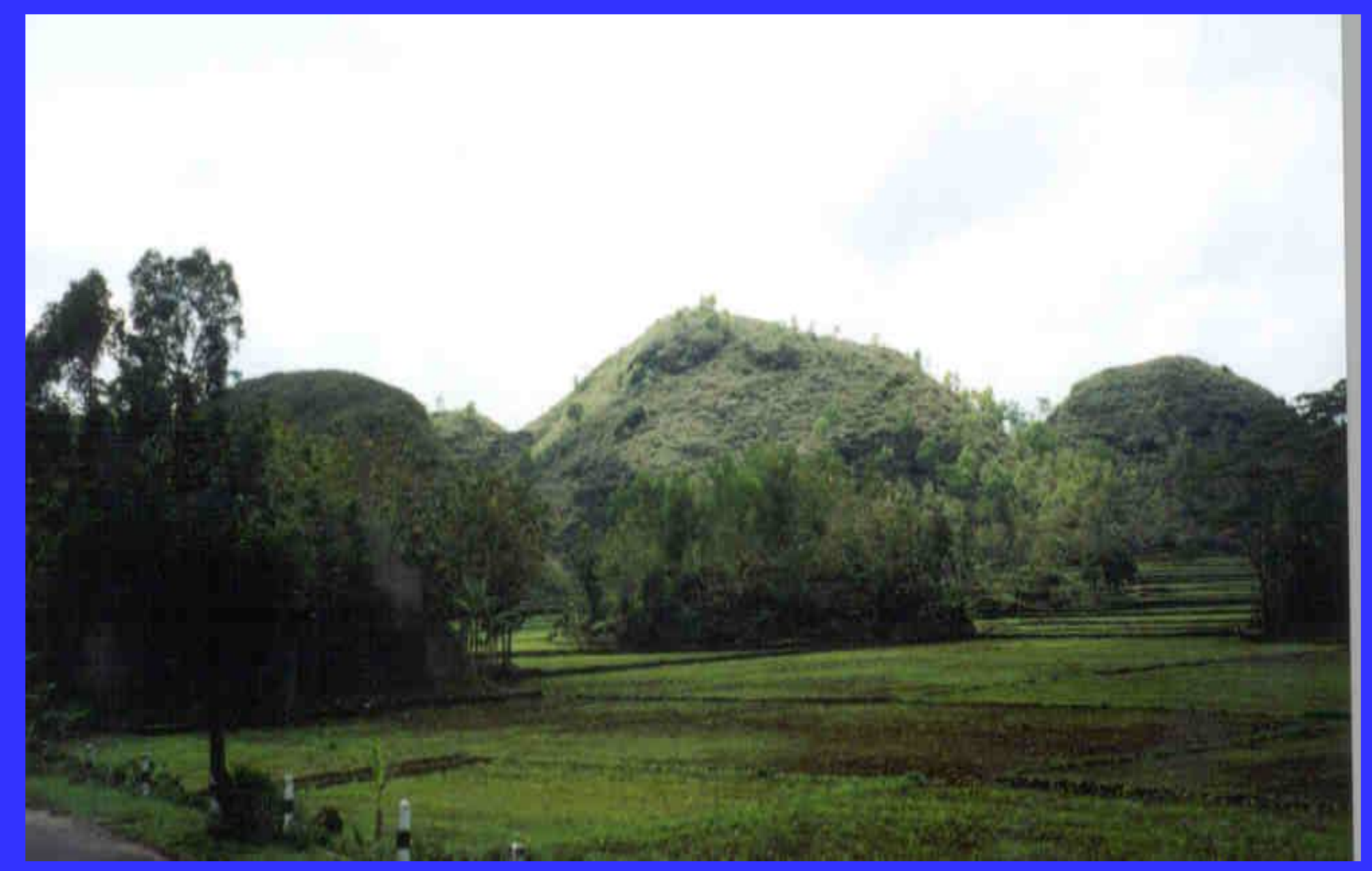




\section{MATAAIR KARST}

\section{- Cepat keruh jtka hujan}

-Jernih terus sepanjang tahun 


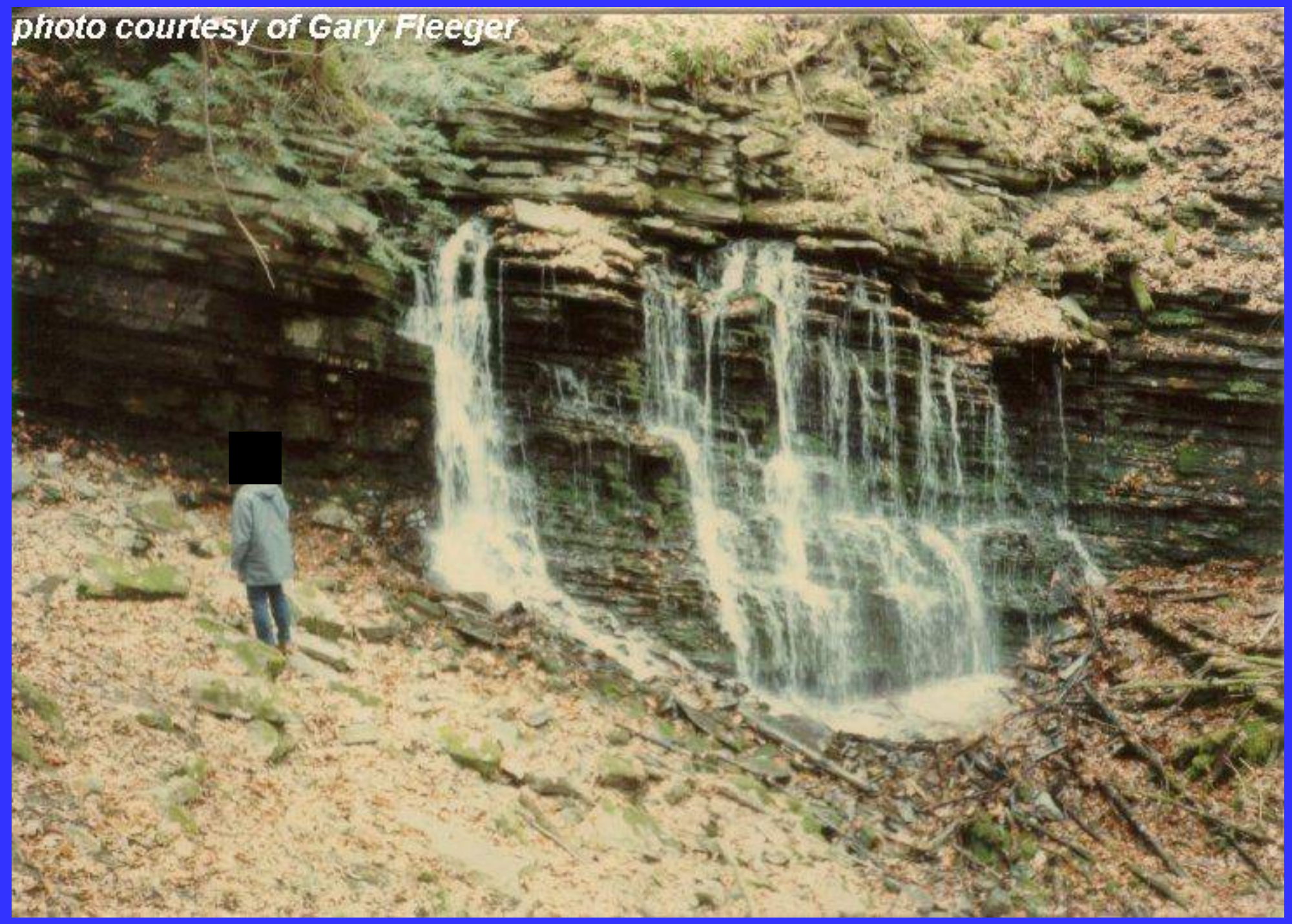




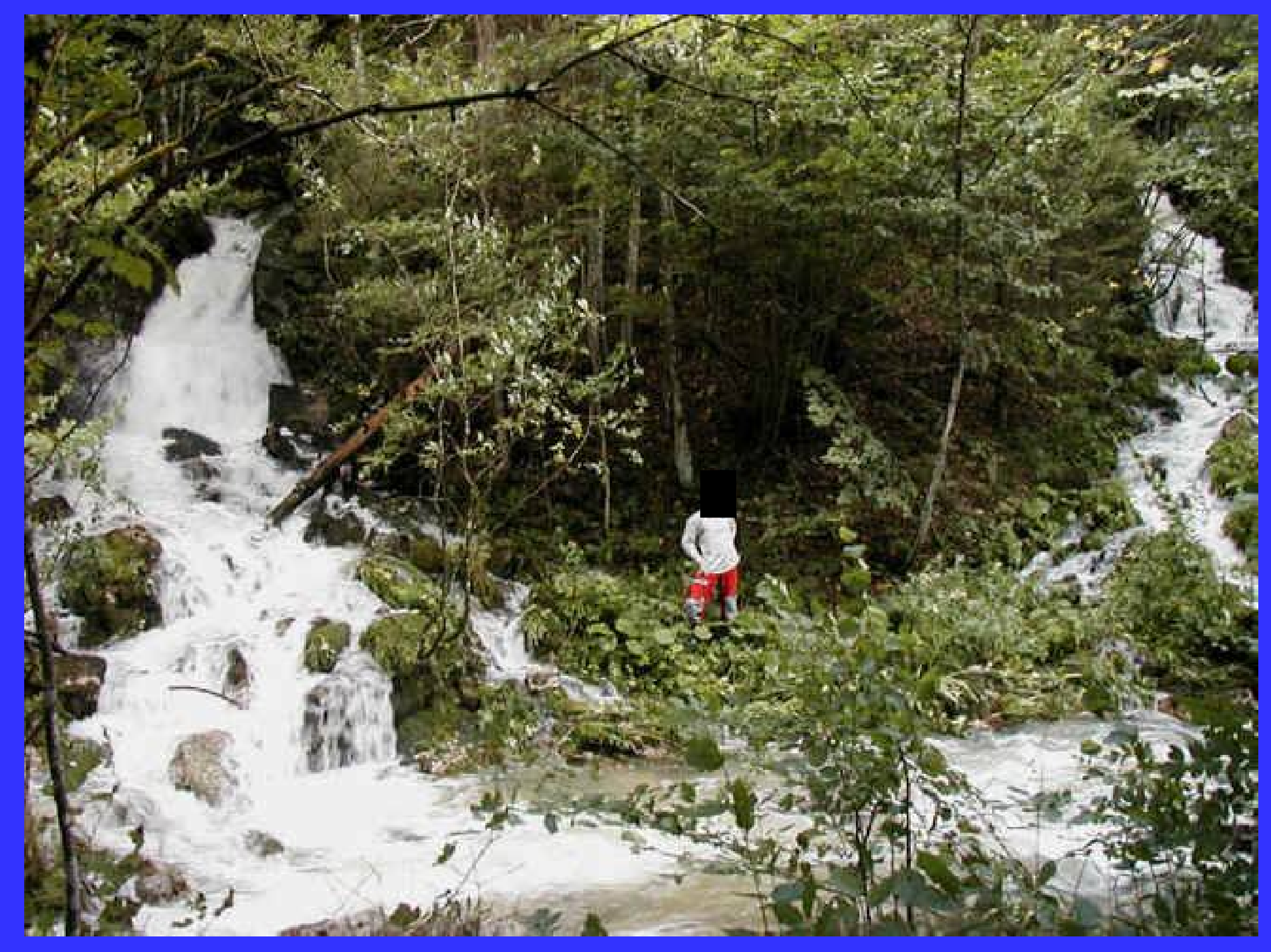




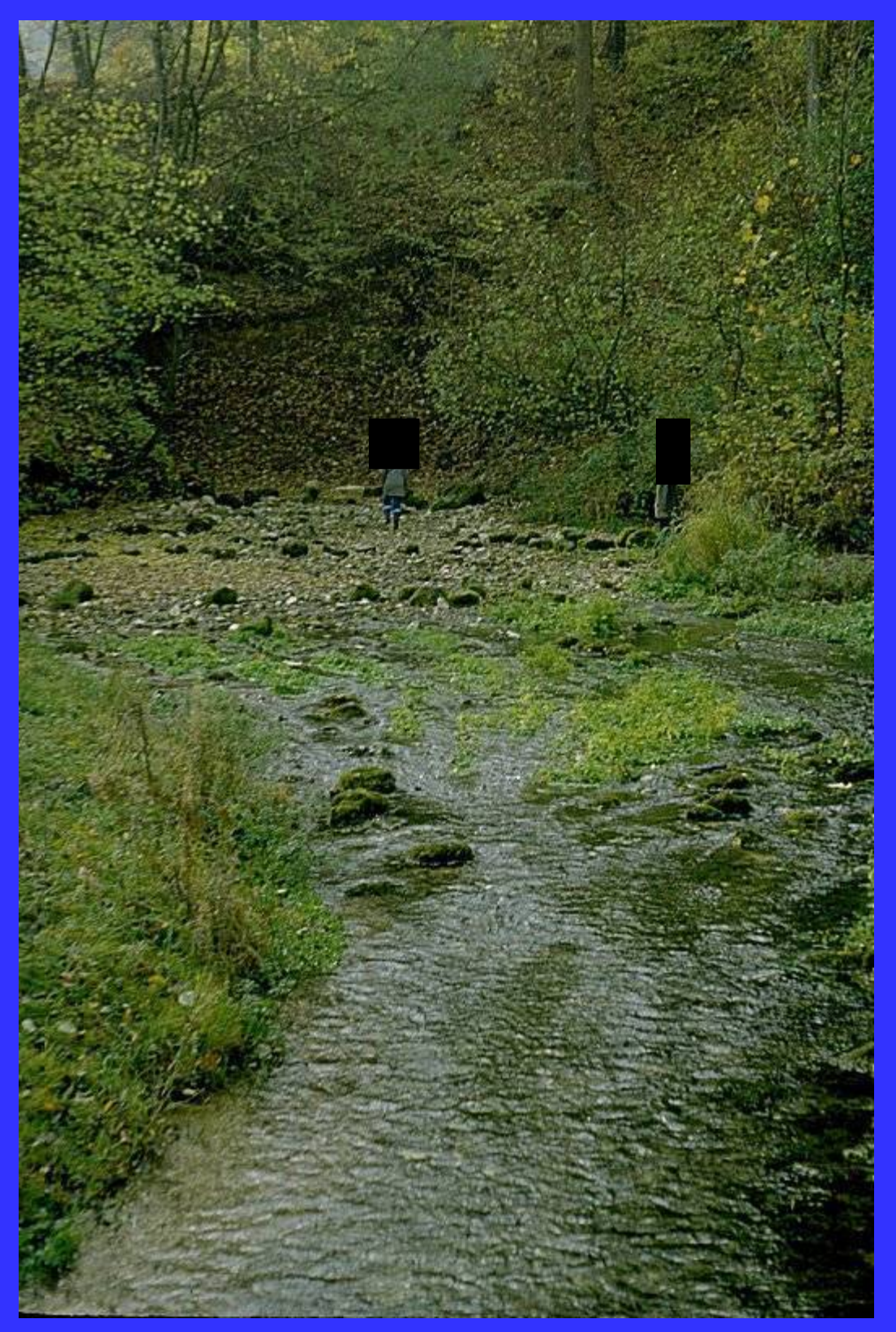




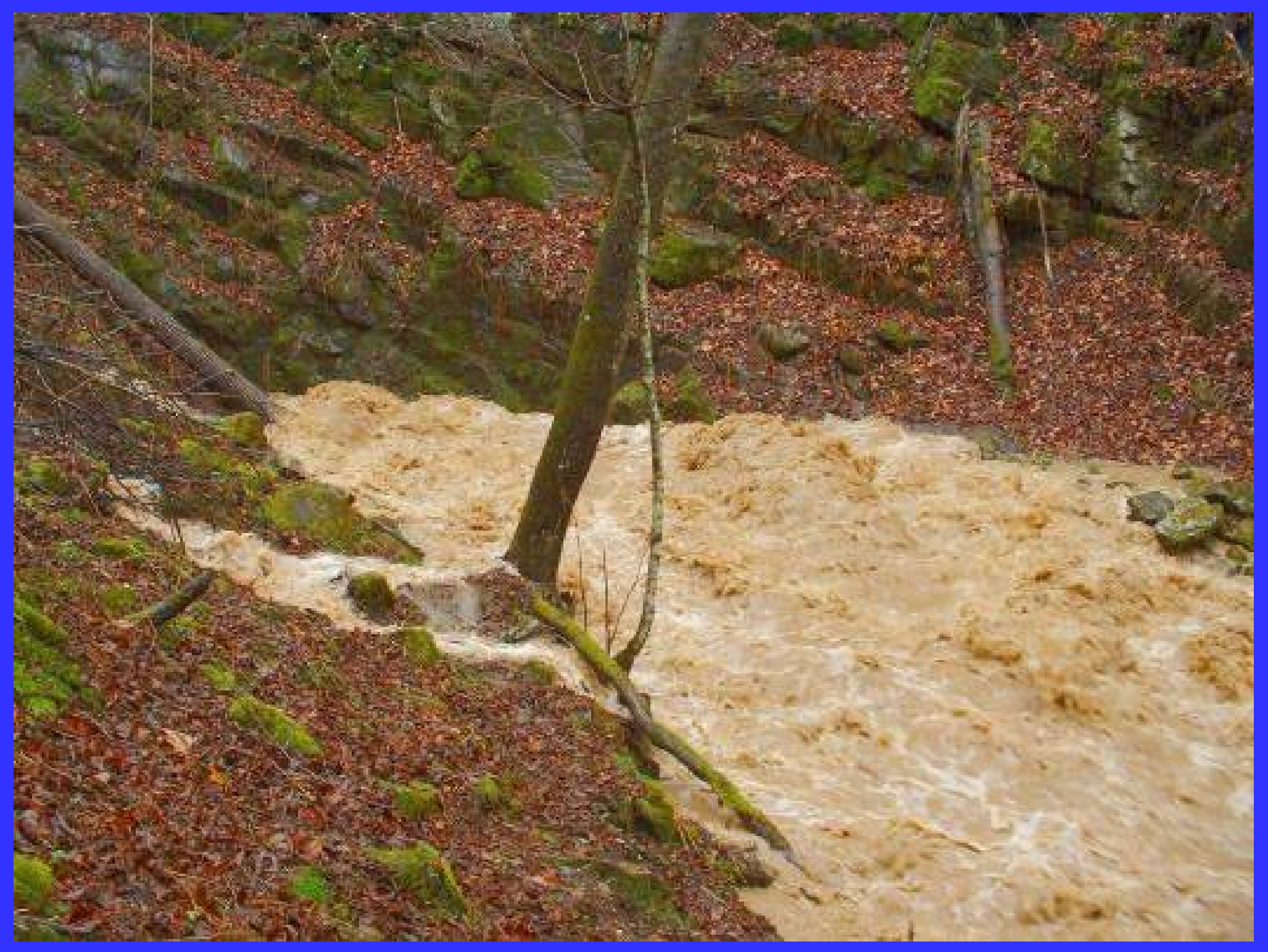




\section{Tandon air di karst}

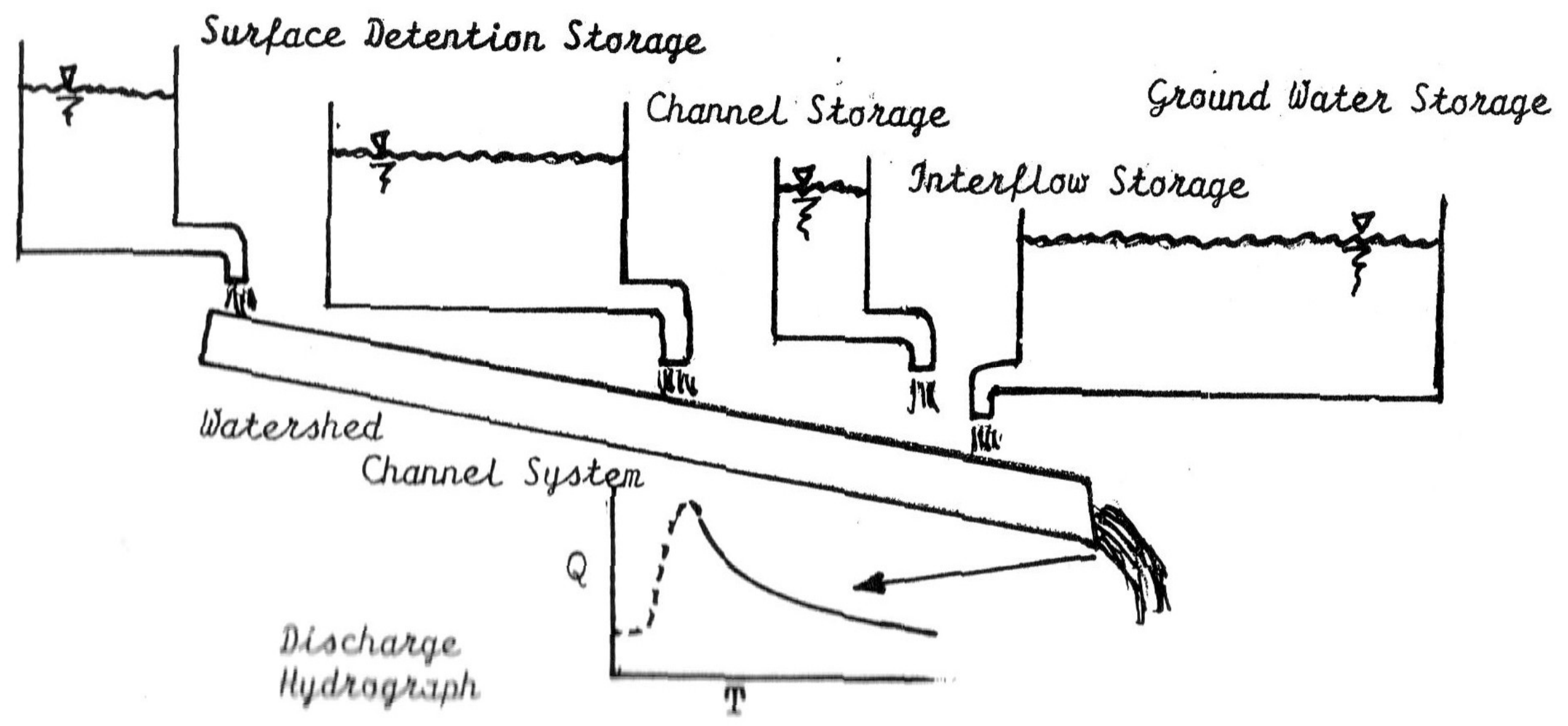




\section{ZONATION OF A KARST AQUIFER}

\section{RECHARGE AREA}

1) Concentrated infiltration

2) Diffuse infiltration

3) Indirect infiltration
EPIPHREATIC ZONE

4) Transfer zone

5) Flow zone

6) Fossil conduits

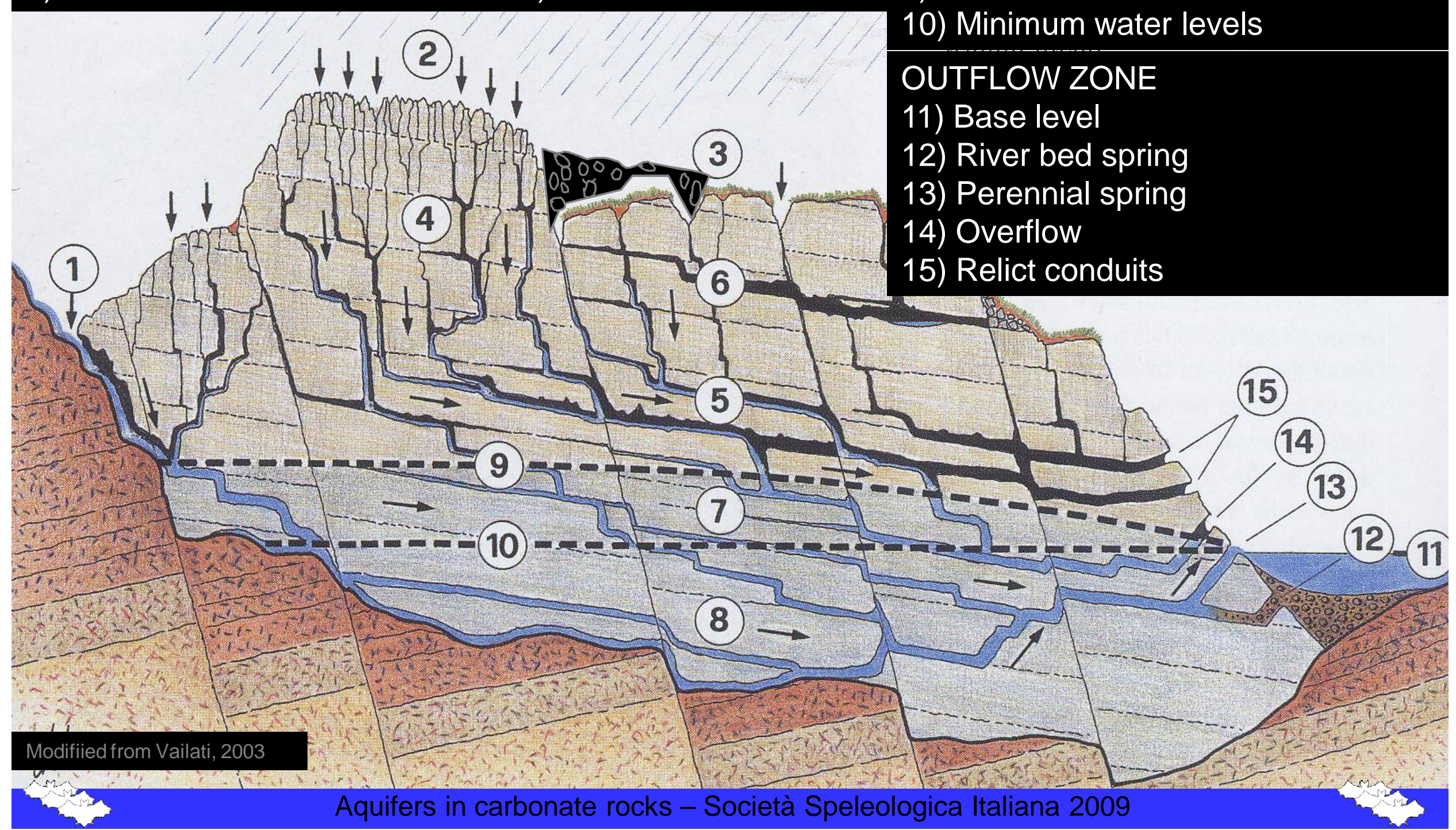

PHREATIC ZONE

7) Oscillation zone

8) Main conduits

9) Maximum water levels

10) Minimum water levels

OUTFLOW ZON

11) Base level

12) River bed spring

13) Perennial spring

15) Relict conduits 


\section{Karst Kerucut}

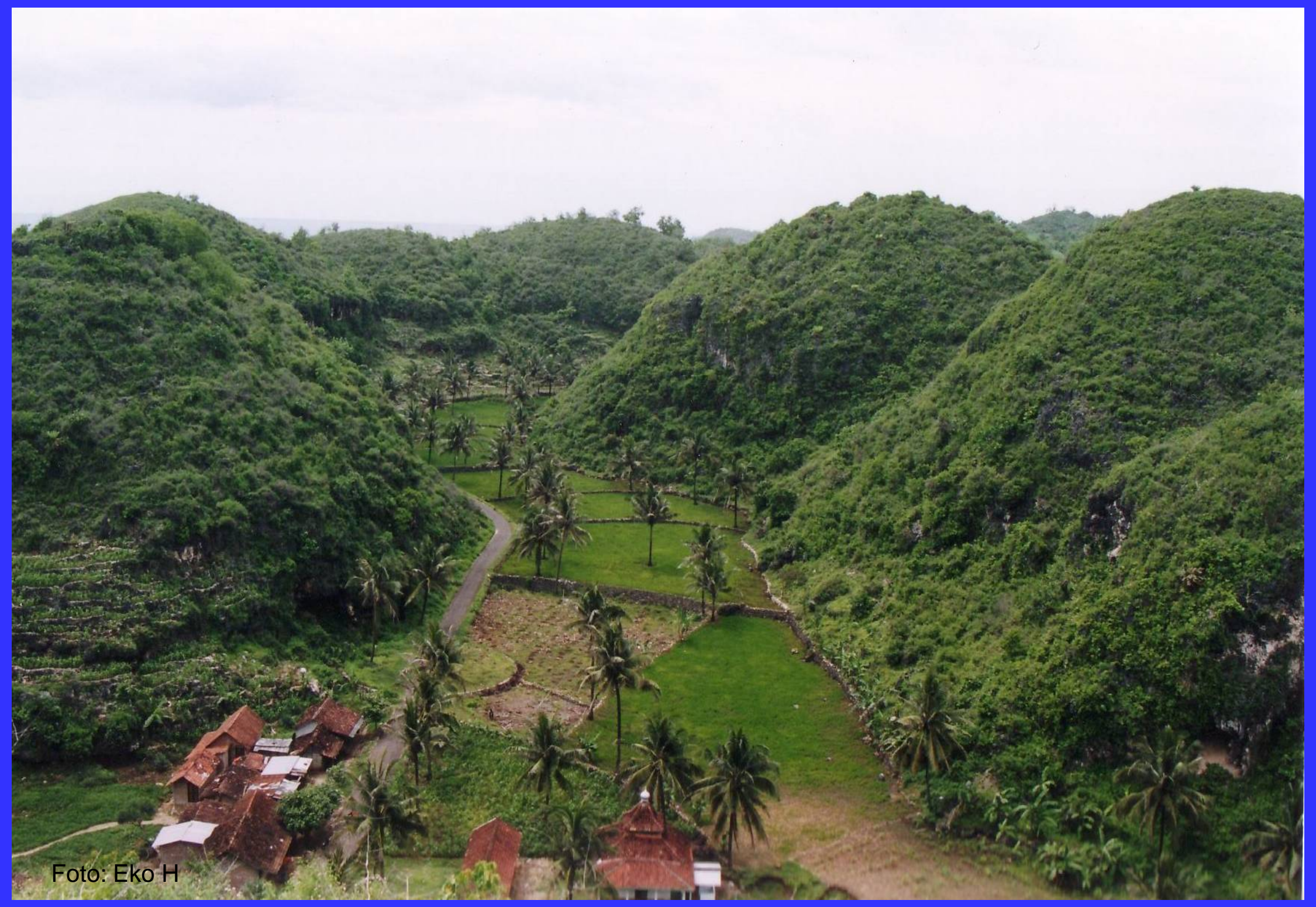




\section{Karst Labirin}

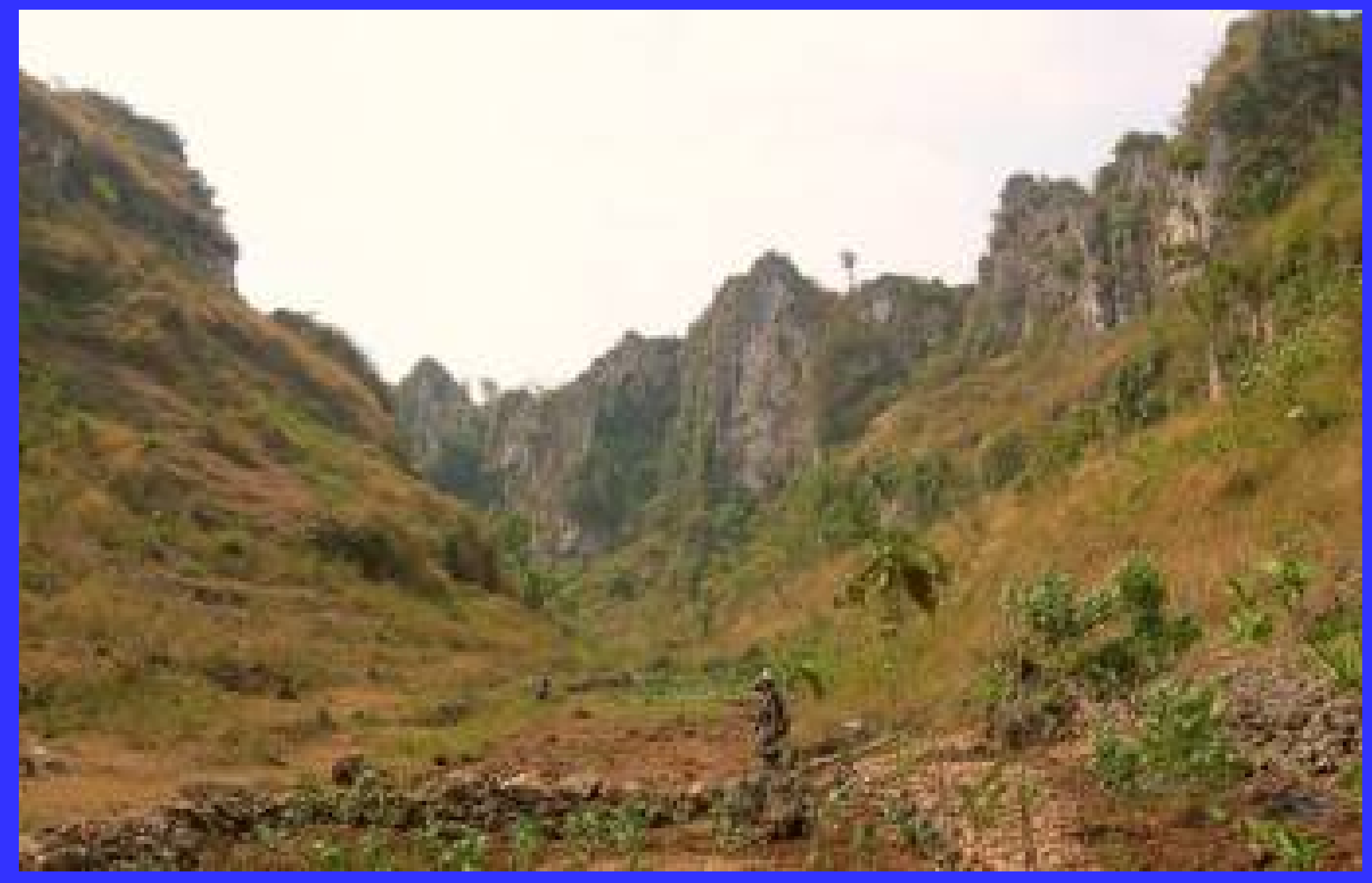

Foto: Eko H 


\section{Menara}

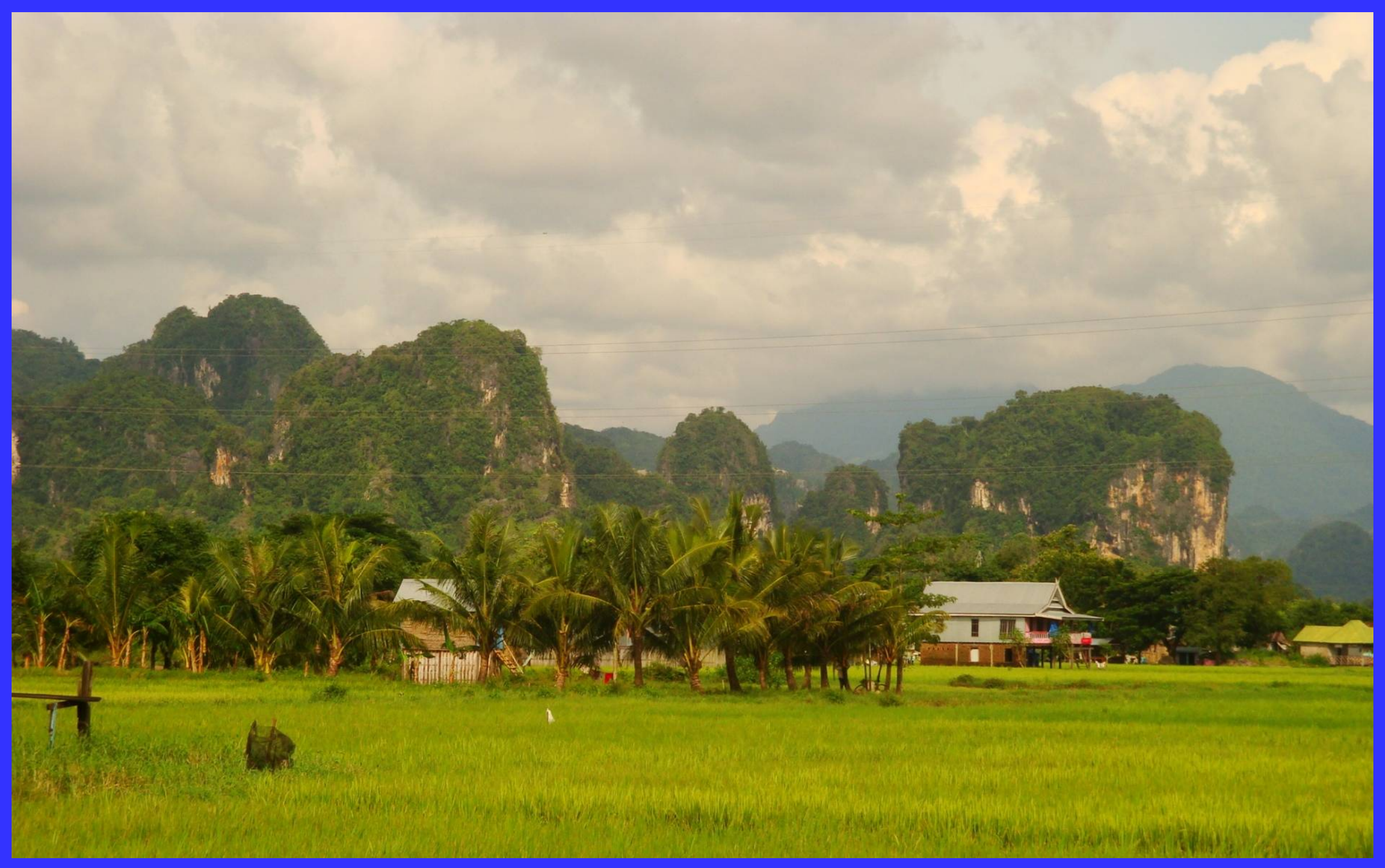

Foto: Eko H 


\section{Karst Pinakle}

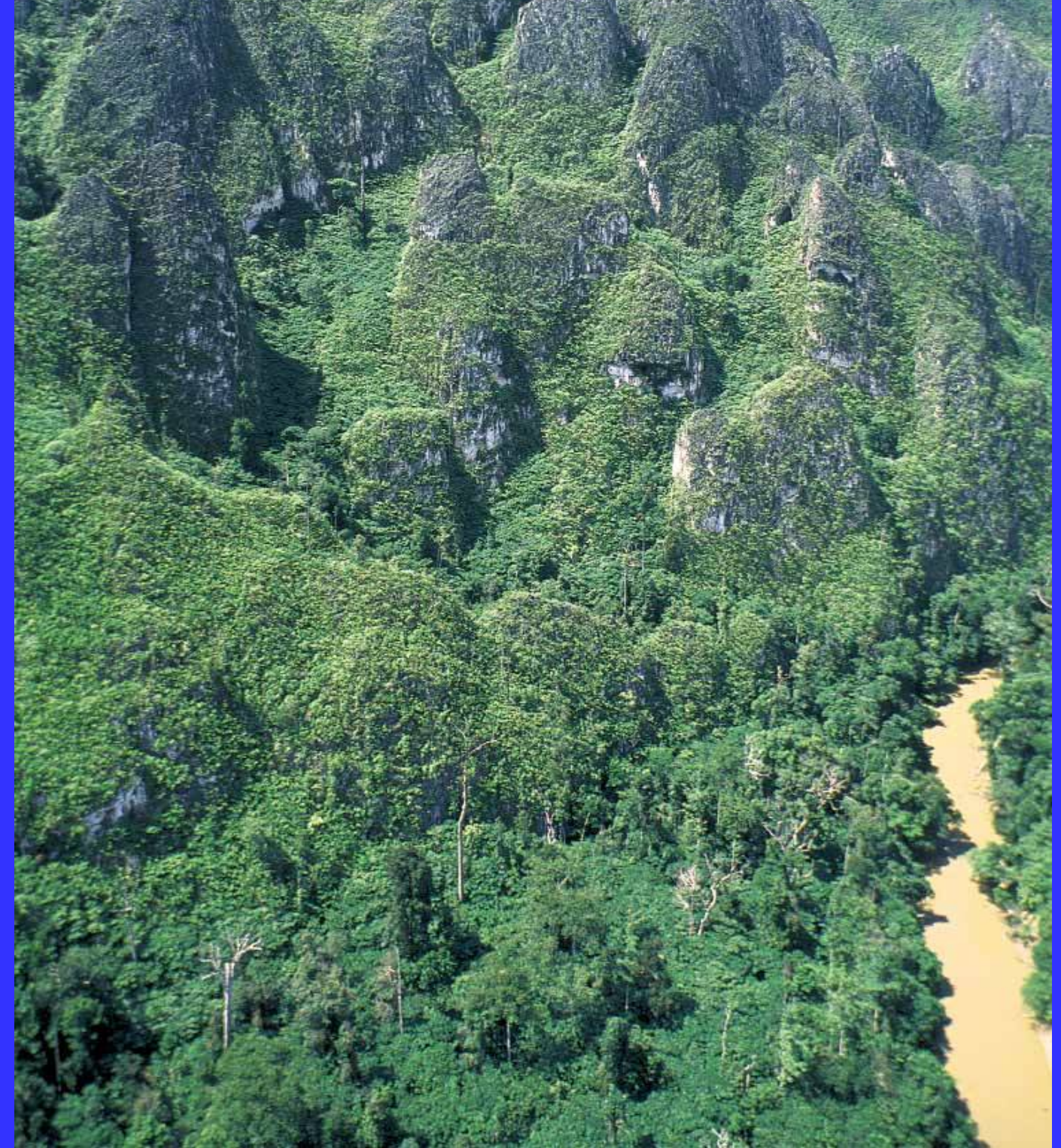




\section{Karst Glasial}

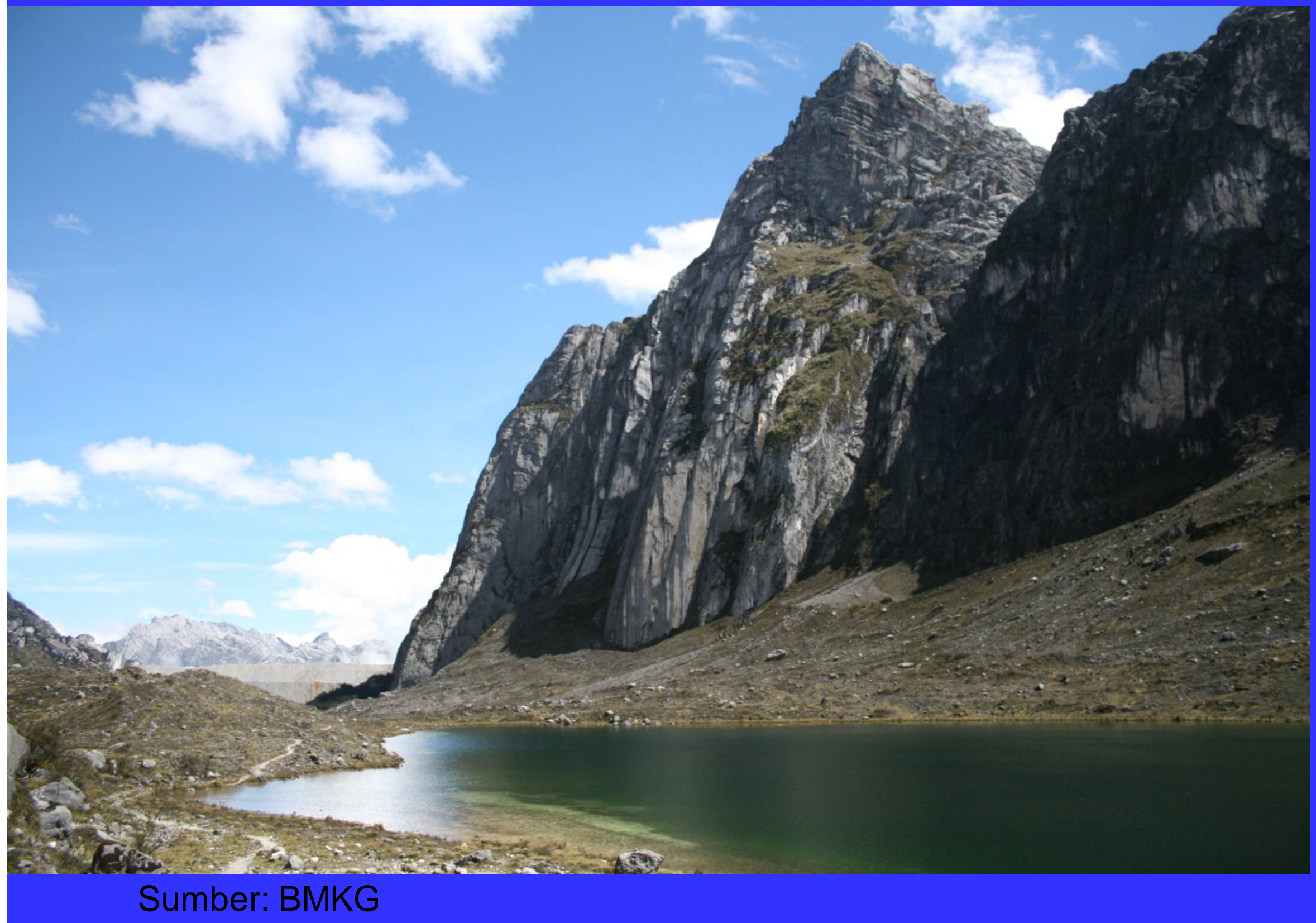




\section{APA JADINYA JIKA BUKIT KARST DITAMBANG ??}

- Penambangan di perbukitan karst akan mengurangi simpanan air yang pada akhirnya akan mengurangi debit sungai bawah tanah dan mataair

..............dan / atau......... 
- Akan merubah pola debit pada maair yaitu berkurang saat musim kemarau, dan banjir bertambah besar ketika musim hujan;

\section{Dan / atau.........}

- Pencemaran bertambah besar , karena tidak akan ada lagi filter atau saringan yang dapat menahan berbagai macam polutan dari permukaan (limbah, pemupukan, sampah, dll) 


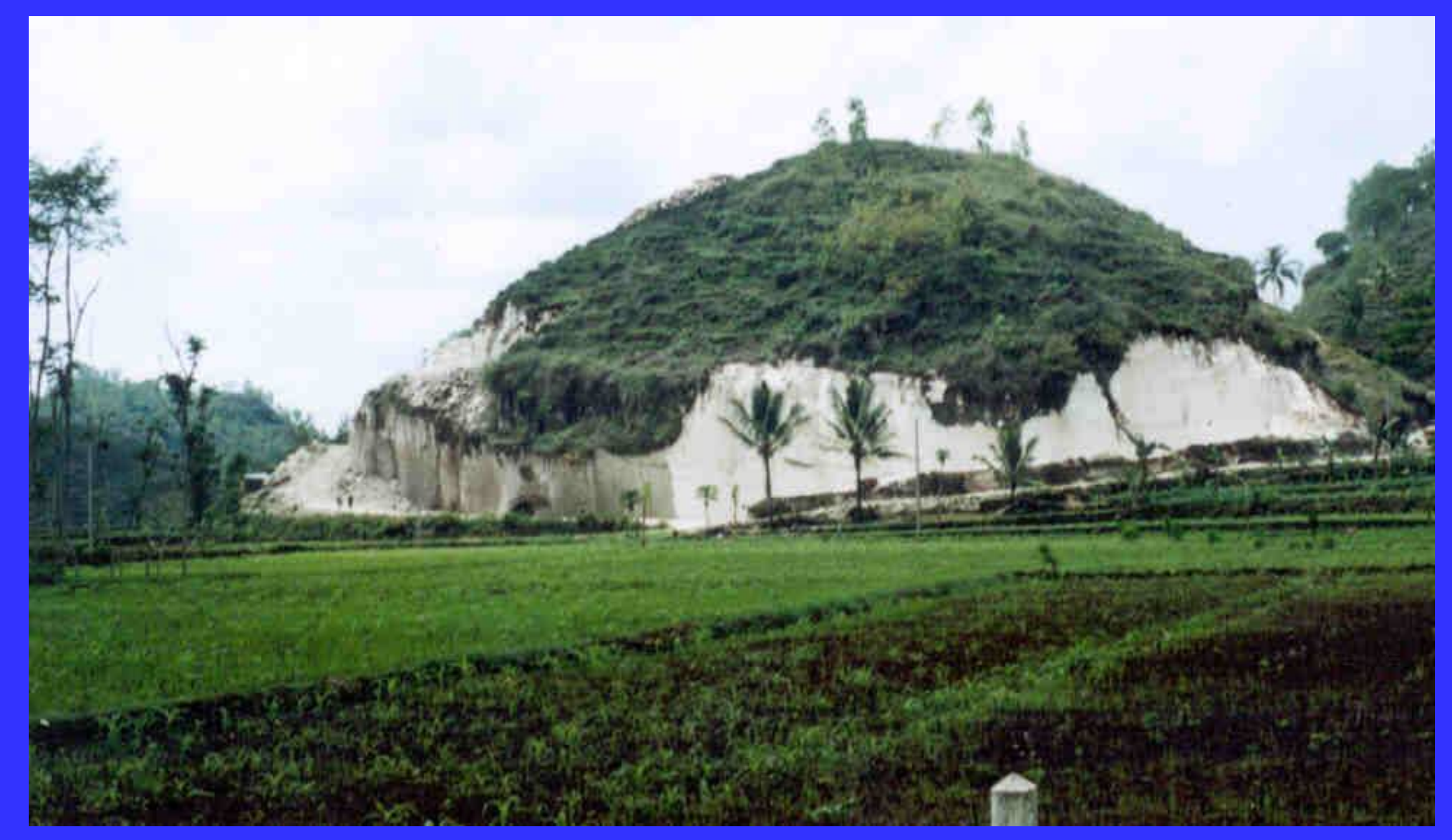

Foto by : Pak Budi (Pertambangan Gunungkidul) 


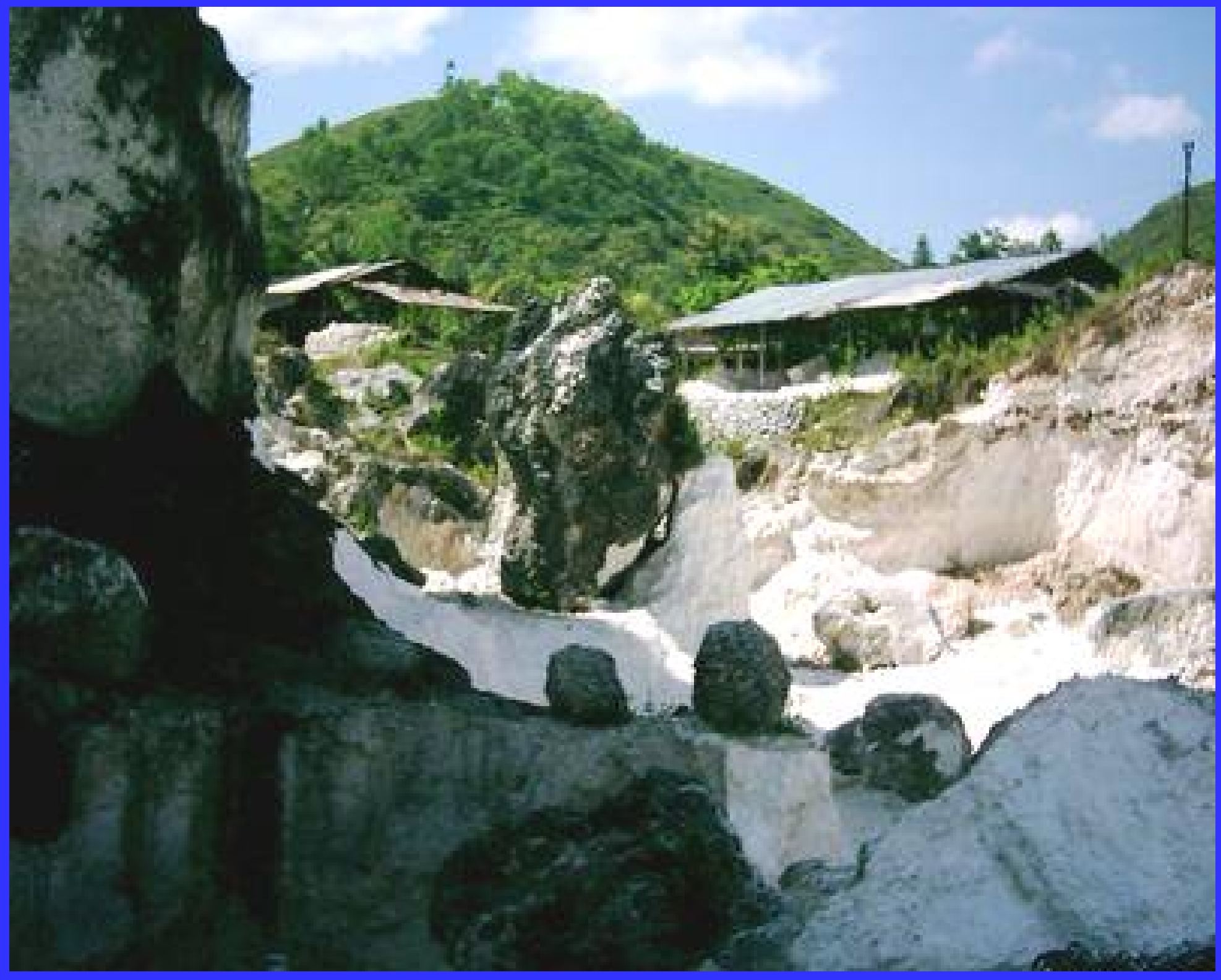

Foto by : Pak Budi (Pertambangan Gunungkidul) 
Ketika proses pelarutan terjadi karst adalah penyerap karbon, pengkonsumsi karbon, dan penyeimbang siklus karbon

$\square$ Mengurangi efek rumah kaca dan pemanasan global

$\square$ rata-rata $\mathrm{CaCO}_{3}$ "dimakan" oleh proses pelarutandi Gunung Sewu Karst is 185 mg/ I

$\square$ tingkat denudation Gunung Sewu Karst diestimasi sebesar $50,91 \mathrm{~m}^{3} / \mathrm{km}^{2} /$ year

$\square$ Setara 165.464 ton $\mathrm{CaCO}_{3} /$ tahun

$\square$ Setara 72.804,16 ton carbondioksida/ tahun 


\section{Catatan:}

$\square$ sebagai sebuah sistem, maka daerah karst mempunyai komponen-komponen yang terkait satu sama lain.

$\square$ mempunyai input atau media penyimpan kemudian output

$\square$ dapat berkurang simpanannya jika media penyimpanan (bagian dari siklus hidrologi) terganggu

$\square$ kegiatan bermotif ekonomi pada sistem ini harus dilakukan dengan penuh kehati-hatian, dibatasi peruntukannya,

$\square$ Jika rusak media penyimpanannya, tidak mungkin dapat dipulihkan kembali dengan cara apapun. 